University of Massachusetts Amherst

From the SelectedWorks of Raymond S Bradley

2015

Winter climate extremes over the northeastern

United States and southeastern Canada and teleconnections with large-scale modes of climate variability

Liang Ning

Raymond S Bradley, University of Massachusetts - Amherst 


\title{
Winter Climate Extremes over the Northeastern United States and Southeastern Canada and Teleconnections with Large-Scale Modes of Climate Variability*
}

\author{
LIANG NING AND RAYMOND S. BRADLEY \\ Northeast Climate Science Center, and Department of Geosciences, University of Massachusetts Amherst, Amherst, Massachusetts
}

(Manuscript received 6 December 2013, in final form 1 December 2014)

\begin{abstract}
The relationship between winter climate extremes across the northeastern United States and adjacent parts of Canada and some important modes of climate variability are examined to determine how these circulation patterns are related to extreme events. Linear correlations between 15 extreme climate indices related to winter daily precipitation, maximum and minimum temperature, and three dominant large-scale patterns of climate variability [the North Atlantic Oscillation (NAO), Pacific-North American (PNA) pattern, and El Niño-Southern Oscillation (ENSO)] were analyzed for the period 1950-99. The mechanisms behind these teleconnections are analyzed by applying composite analysis to the geopotential height, sea level pressure (SLP), moisture flux, and wind fields. Pressure anomalies and associated airflow patterns related with the different modes of climate variability explain the patterns of temperature and precipitation extremes across the region. The responses of the daily scale climate extremes to the seasonally averaged large-scale circulation patterns are achieved through shifts in the probability distributions.
\end{abstract}

\section{Introduction}

Because of their large societal impacts, climate extremes have attracted increasing attention in recent climate studies (Easterling et al. 2000; Meehl and Tebaldi 2004). Heavy precipitation events, droughts, and high temperatures have increased in the United States in recent decades, along with the rise of global mean surface temperature (Trenberth et al. 2007). These trends are also confirmed by other studies of climate extremes on a global scale (Frich et al. 2002; Alexander et al. 2006). For example, Villarini et al. (2013) showed increasing trends of heavy rainfall over the northern part of the central United States and related the increase to higher levels of atmospheric water vapor brought about by rising temperatures. Similarly, Ning and Qian (2009) found that there has been a significant increase in summer extreme precipitation over south China since the

\footnotetext{
* Supplemental information related to this paper is available at the Journals Online website: http://dx.doi.org/10.1175/JCLI-D-13-00750.s1.

Corresponding author address: Liang Ning, Dept. of Geosciences, University of Massachusetts Amherst, 134 Morrill Building, Amherst, MA 01003.

E-mail: lning@geo.umass.edu
}

early 1990s due to interdecadal variations of latent heat flux over the South China Sea and sensible heat flux over Indochina. By applying downscaling methods, Goodess et al. (2005) found increases in the frequency and intensity of high-temperature extremes and decreases in the frequency and intensity of lowtemperature extremes throughout Europe, together with more spatially and seasonally variable changes in the occurrence of rainfall extremes.

Previous studies (e.g., Kenyon and Hegerl 2008; Brown et al. 2008; Kenyon and Hegerl 2010; Westby et al. 2013) have shown that several prominent largescale circulation modes, such as the North Atlantic Oscillation (NAO; Wallace and Gutzler 1981; Barnston and Livezey 1987), Pacific-North American (PNA; Wallace and Gutzler 1981; Leathers et al. 1991) pattern, and El Niño-Southern Oscillation (ENSO; Trenberth 1997) have strong influences on temperature and precipitation extremes over different regions. For example, over the contiguous United States, Gershunov and Barnett (1998) examined the signature of ENSO in the wintertime frequencies of heavy precipitation and temperature extremes and found ENSO signals in the frequency of occurrence of heavy rainfall in the U.S. Southeast, Gulf Coast, central Rockies, and the general area of the Mississippi-Ohio River valleys and strong, nonlinear 
signals in extreme warm-temperature frequencies were found in the southern and eastern United States. When focusing on the relationship between winter temperature extremes and ENSO over the United States, Higgins et al. (2002) also found that the number of daily extremes is reduced during El Niño years at most locations but increased during La Niña and ENSO-neutral years. Westby et al. (2013) evaluated the low-frequency modulation from NAO, PNA, ENSO, and Pacific decadal oscillation (PDO) on anomalous temperature regimes [i.e., cold air outbreaks and warm waves during the boreal winter over the continental United States, as simulated by general circulation models (GCMs) from phase 5 of the Coupled Model Intercomparison Project (CMIP5)]. Over the western United States, frequency distributions of daily precipitation in winter and daily streamflow from late winter to early summer were found to exhibit strong and systematic responses to the two phases of ENSO (Cayan et al. 1999).

Over the northeastern United States and southeastern Canada, previous studies have shown that NAO, PNA, and ENSO have strong influences on both the mean climate (e.g., Ropelewski and Halpert 1986; Hartley and Keables 1998; Kunkel and Angel 1999; Bradbury et al. 2003; Ning et al. 2012a,b; Ning and Bradley 2014) and climate extremes in the region (e.g., Wettstein and Mearns 2002; Bradbury et al. 2002a; Griffiths and Bradley 2007). A dipole of NAO influence in which positive-NAO years bring warmer winter temperatures to the northeastern United States but colder winter temperatures in Quebec was found by Hurrell and van Loon (1997). Then, Wettstein and Mearns (2002) found that the relationships between the North Atlantic Oscillation-Arctic Oscillation (NAO-AO) and local temperature response (including the mean and daily variance) throughout the northeastern United States and neighboring areas of Canada can explain significant increases in maximum temperature extremes during winter in New England and in minimum temperature extremes during spring in Quebec for high-NAO-AO index years. These results are consistent with the conclusions of Brown et al. (2008) that NAO has a significant influence on extreme winter daily temperatures over the northeastern United States, with positive NAOs associated with more warm-temperature extremes. Griffiths and Bradley (2007) also indicate that AO is a good predictor of winter warm nights, while ENSO is a good predictor of consecutive dry days in the northeastern United States. When examining the influence of the PNA, northern annular mode (NAM), and ENSO on extreme temperature days and months for North American winters and summers, Loikith and Broccoli (2014) found that the PNA and NAM play important roles in the occurrence of extreme temperature days in regions in the vicinity of the characteristic atmospheric circulation anomalies associated with these modes of variability, while ENSO tends to have a weaker relationship, because the sea surface temperature anomalies over the equatorial Pacific Ocean have a less direct influence than the local atmospheric circulation. In this study, we systemically examine the relationships between the NAO, PNA, and ENSO and 15 winter climate extremes, which are significant for regional hydrology, ecosystems, and human health. We then explore the physical mechanisms behind these relationships.

\section{Data and methodology}

The study area covers the entire northeastern quadrant of the United States and adjacent parts of Canada $\left(36^{\circ}-\right.$ $\left.50^{\circ} \mathrm{N}, 100^{\circ}-68^{\circ} \mathrm{W}\right)$. The high-resolution $\left(1 / 8^{\circ}\right)$ observed daily precipitation data used in this analysis are for the period 1950-99, as described in Maurer et al. (2002).

The standardized monthly NAO, PNA, and Niño-3.4 indices $\left(5^{\circ} \mathrm{N}-5^{\circ} \mathrm{S}, 170^{\circ}-120^{\circ} \mathrm{W}\right)$ for the period $1950-99$ are from NOAA's Climate Prediction Center (CPC). The winter indices are averaged for December-March (DJFM), as in previous studies (Kunkel and Angel 1999; Bradbury et al. 2003), because winter conditions usually persist until March over this region, especially over the New England area. The monthly gridded $1000-300-\mathrm{hPa}$ zonal $u$ and meridional $v$ components of the wind, 1000-500-hPa specific humidity, 300-hPa geopotential height, and sea level pressure (SLP) fields with a resolution of $2.5^{\circ} \times 2.5^{\circ}$ for the period $1950-99$ are used in the composite analysis [from the National Centers for Environmental Prediction (NCEP) reanalysis datasets].

The vertically integrated low-level average moisture flux components for winter season were calculated using the following equations (Coleman and Rogers 2003; Dominguez and Kumar 2005):

$$
\begin{aligned}
& q u=\frac{1}{g} \int_{1000 \mathrm{hPa}}^{500 \mathrm{~Pa}} \bar{q} \bar{u} d p \quad \text { and } \\
& q v=\frac{1}{g} \int_{1000 \mathrm{hPa}}^{500 \mathrm{hPa}} \bar{q} \bar{v} d p
\end{aligned}
$$

where $q u$ and $q v$ are the zonal and meridional moisture flux components, and $\bar{q}, \bar{u}$, and $\bar{v}$ are the seasonal mean specific humidity and the zonal and meridional wind components at each pressure level. The two-dimensional moisture flux field was calculated by

$$
\mathbf{q}=q u \mathbf{i}+q v \mathbf{j},
$$


where $\mathbf{q}$ is the low-level horizontal moisture flux, and $\mathbf{i}$ and $\mathbf{j}$ are the unit zonal and meridional vectors.

The 15 indices of climate extremes used in this study are listed and defined in Table 1. These indices are taken from the dictionary of European Climate Assessment and Dataset (ECA\&D), which has been commonly used in previous studies about climate extremes (Frich et al. 2002; Meehl and Tebaldi 2004; Alexander et al. 2006). These 15 indices cover a wide range of interdisciplinary interests and concerns about the potential impacts of climate change. For example, total numbers of cold days Tx10p and cold nights Tn10p have strong influence on winter energy usage. The minimum values of daily maximum temperature and minimum temperature are important in agricultural decision making. The number of days with daily precipitation larger than $10 \mathrm{~mm}$ is an important factor in driving hydrological models.

\section{Results}

\section{a. Relationships with the large-scale climate variability}

To investigate the relationships between winter climate extremes and large-scale climate variability, linear correlation coefficients between the 15 extreme indices and the three circulation indices were first calculated. When correlation analysis is applied to examine the ENSO teleconnections, one potential issue is that the nonsymmetric influences from El Niño and La Niña (An et al. 2007; Kug et al. 2010) due to nonlinear phase shifts (Hoerling et al. 1997) may not be fully examined. However, investigation of the nonlinear component of ENSO teleconnections is beyond the scope of this paper, and in order to keep the methodology consistent with the NAO and PNA analysis, we mainly focus on the linear component of the ENSO teleconnections in this study.

The correlation patterns between the NAO, PNA, and ENSO indices and mean values of winter daily maximum temperature Tmax and minimum temperature Tmin are shown in Fig. 1. The NAO index has positive correlations with mean values of winter daily Tmax and Tmin over nearly all the region, and most of the correlations are significant at the $95 \%$ level based on a Student's $t$ test (Figs. 1a,b). The PNA index has significant positive correlations with the mean values of winter daily Tmax and Tmin over most parts of the region in the north, especially the northwestern part, and negative correlations to the southeast (Figs. 1c,d). For the Niño-3.4 index, the north-south seesaw correlation pattern of the mean values of winter daily Tmax and Tmin is similar to the PNA results, but the spatial patterns shift to the east (Figs. 1e,f).
TABLE 1. The definitions and units of the 15 climate extreme indices used in this study.

\begin{tabular}{|c|c|c|}
\hline Index & Definition & Unit \\
\hline Tx90p & $\begin{array}{l}\text { Warm days (number of days with } \\
\text { max temperature higher than 90th } \\
\text { percentile of daily max temperature) }\end{array}$ & Days \\
\hline Tx10p & $\begin{array}{l}\text { Cold days (number of days with max } \\
\text { temperature lower than 10th } \\
\text { percentile of daily max temperature) }\end{array}$ & Days \\
\hline TX & Mean of daily max temperature & ${ }^{\circ} \mathrm{C}$ \\
\hline TXn & Min of daily max temperature & ${ }^{\circ} \mathrm{C}$ \\
\hline TXx & Max of daily max temperature & ${ }^{\circ} \mathrm{C}$ \\
\hline $\operatorname{Tn} 90 \mathrm{p}$ & $\begin{array}{l}\text { Warm nights (number of days with min } \\
\text { temperature higher than 90th percentile } \\
\text { of daily min temperature) }\end{array}$ & Days \\
\hline Tn10p & $\begin{array}{l}\text { Cold nights (number of days with min } \\
\text { temperature lower than 10th } \\
\text { percentile of daily min temperature) }\end{array}$ & Days \\
\hline $\mathrm{TN}$ & Mean of daily min temperature & ${ }^{\circ} \mathrm{C}$ \\
\hline $\mathrm{TNn}$ & Min of daily min temperature & ${ }^{\circ} \mathrm{C}$ \\
\hline $\mathrm{TNx}$ & Max of daily min temperature & ${ }^{\circ} \mathrm{C}$ \\
\hline $\mathrm{R} 95 \mathrm{p}$ & $\begin{array}{l}\text { Number of days with daily precipitation } \\
\text { larger than 95th percentile of daily } \\
\text { precipitation amount }\end{array}$ & Days \\
\hline R95pTOT & $\begin{array}{l}\text { Total precipitation amount due to daily } \\
\text { precipitation larger than } 95 \text { th percentile } \\
\text { of daily precipitation amount }\end{array}$ & $\mathrm{mm}$ \\
\hline Rx5day & $\begin{array}{l}\text { Max total precipitation of } \\
5 \text { continuous days }\end{array}$ & $\mathrm{mm}$ \\
\hline $\mathrm{R} 10 \mathrm{~mm}$ & $\begin{array}{l}\text { Number of days with daily precipitation } \\
\text { larger than } 10 \mathrm{~mm}\end{array}$ & Days \\
\hline CDD & $\begin{array}{l}\text { Max number of consecutive dry days } \\
\quad \text { (daily precipitation }<1 \mathrm{~mm} \text { ) }\end{array}$ & Days \\
\hline
\end{tabular}

Figures 2 and 3 show the correlation coefficients between the seasonal numbers of winter warm days and nights, and cold days and nights $(>90$ th or $<10$ th percentile of Tmax and Tmin, respectively) and the NAO, PNA, and Niño-3.4 indices. The NAO index has significant positive correlations with the number of warm extremes over most of the region (Figs. 2a,b). By contrast, the NAO index has more significant negative correlations with the number of cold extremes over most parts of the region, except for the northeastern corner (Figs. 3a,b). Thus, during positive-NAO winters, there are generally more warm days over the region, with opposite conditions during negative-NAO years. The PNA index has strong positive correlations with the number of warm extremes over most parts of the region in the north and negative correlations to the south (Figs. 2c,d). For cold extremes (Figs. 3c,d), the PNA index has a stronger northwestsoutheast gradient (negative to positive correlations). For the Niño-3.4 index, the north-south seesaw correlation pattern of warm extremes is similar to the PNA results, but the correlations are weaker (Figs. 2e,f). For cold extremes, the correlations are weak but broadly 


\section{Mean of Tmax}

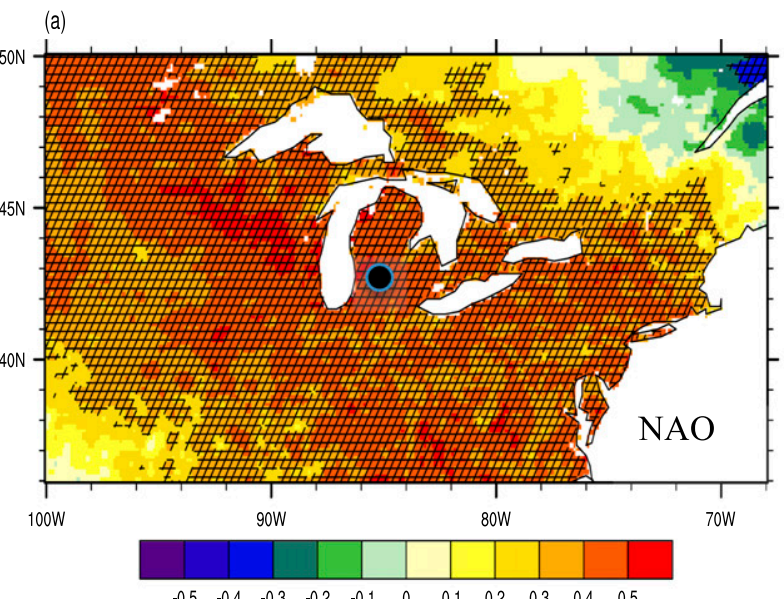

(c)

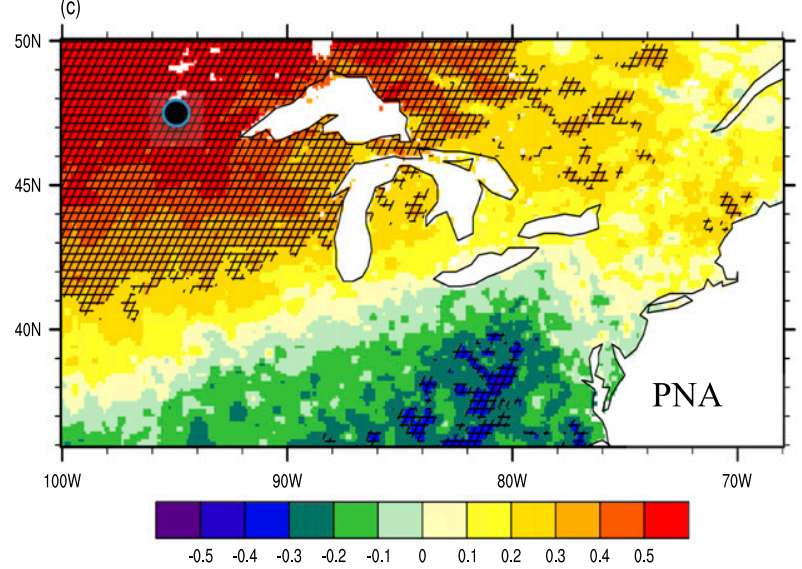

(e)

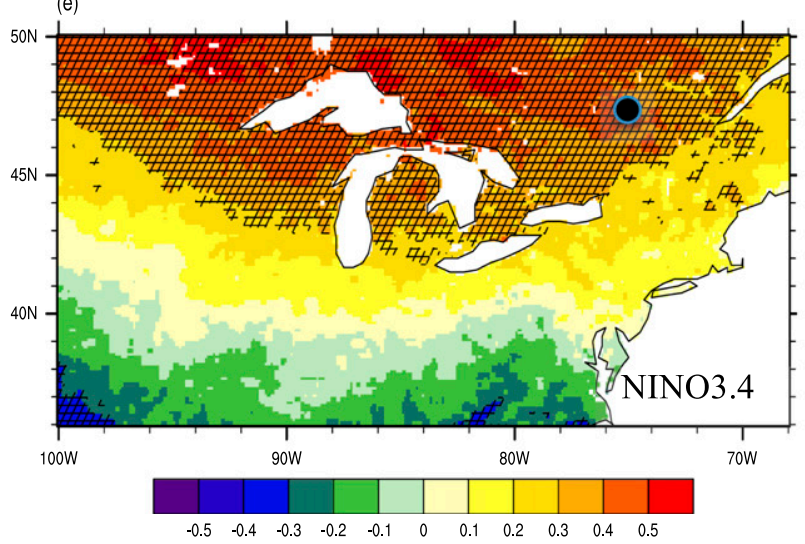

\section{Mean of Tmin}

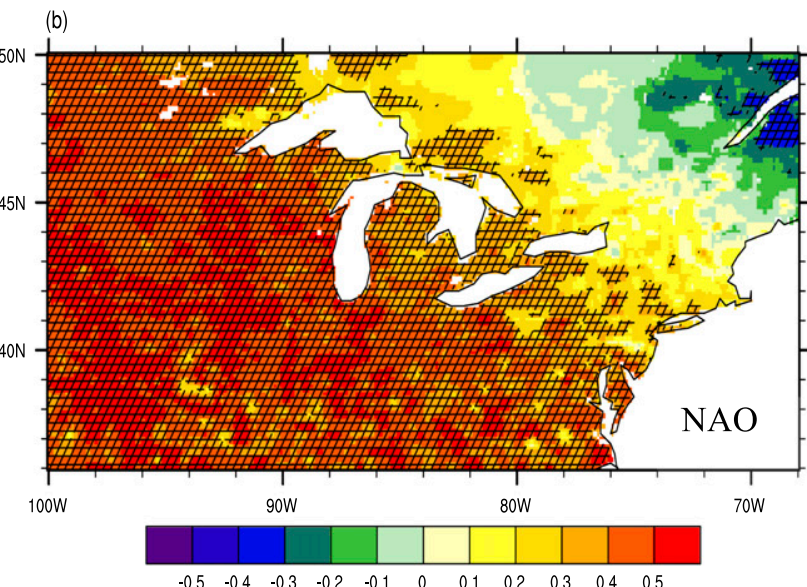

(d)

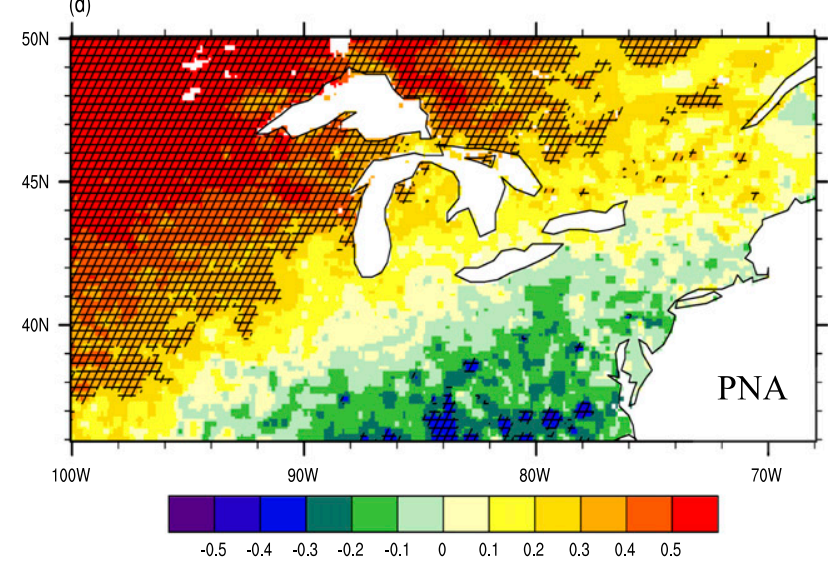

(f)

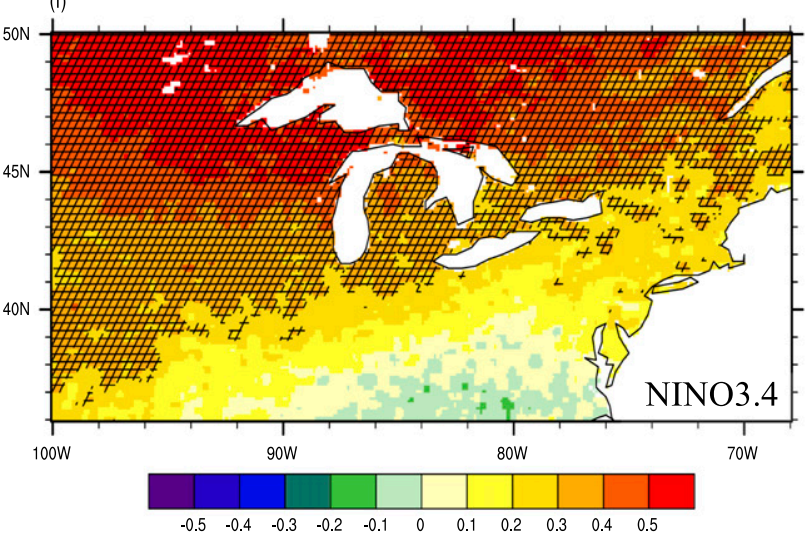

FIG. 1. The correlation coefficients between the mean winter daily (left) Tmax and (right) Tmin and the (a),(b) NAO; (c),(d) PNA; and (e),(f) Niño-3.4 indices. The stippling indicates the correlation coefficients significant at the $95 \%$ level. The dots indicate the locations used in the PDF calculation in Fig. 12.

negative across most of the region, especially in the north and northeast (Figs. 3e,f). One notable characteristic of Fig. 2 is that the correlations with the number of warm nights (Figs. 2b,d,f) are more significant than the correlations with the number of warm days (Figs. 2a,c,d), indicating that the right tail of the daily minimum temperature distribution is more sensitive to the large-scale modes of climate variability. One possible reason for this 


\section{Number of warm days}

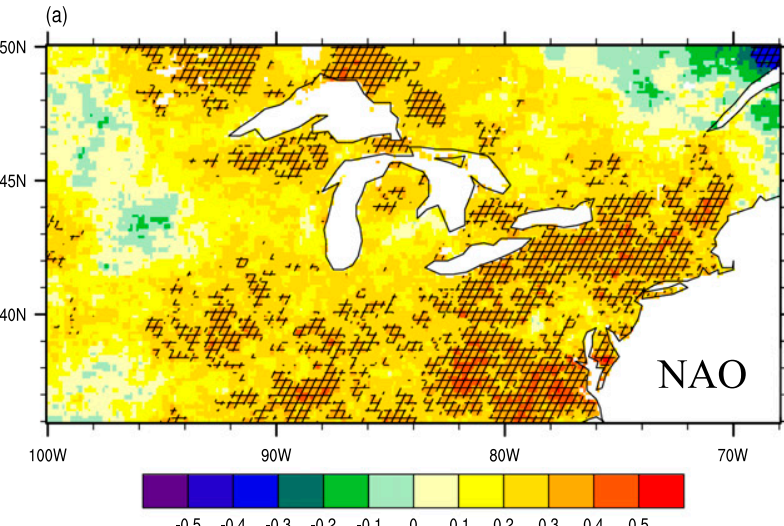

(c)
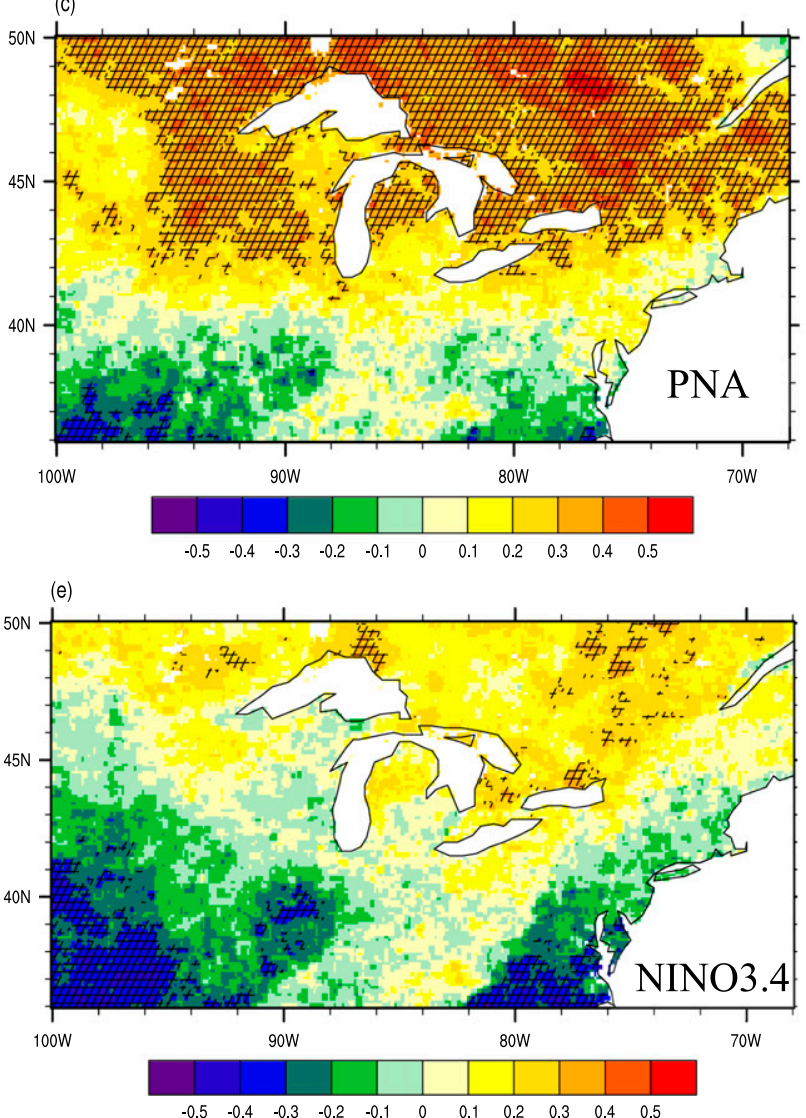

Number of warm nights

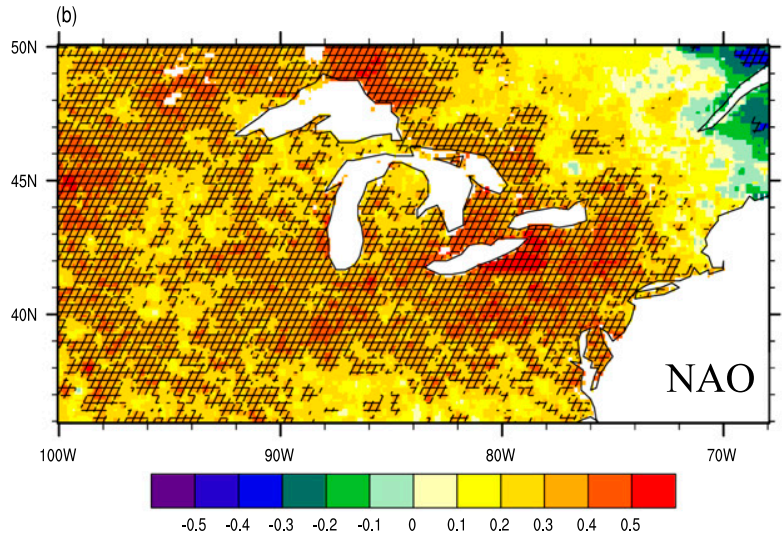

(d)

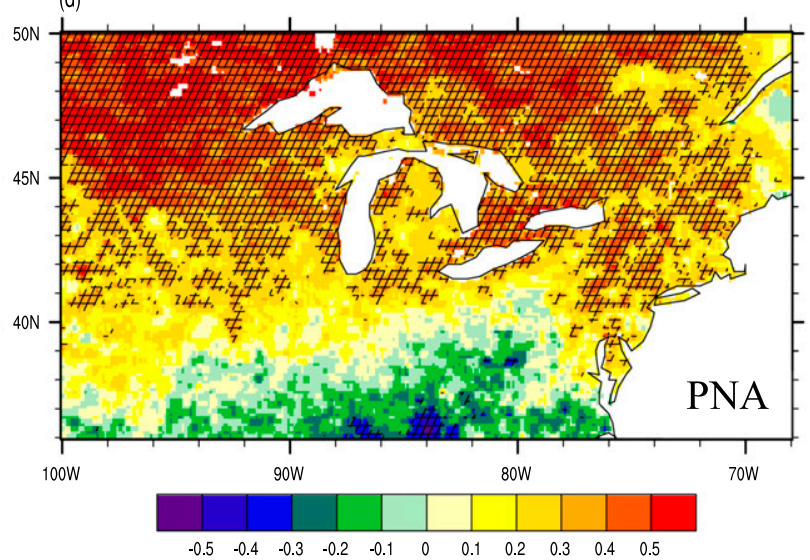

(f)

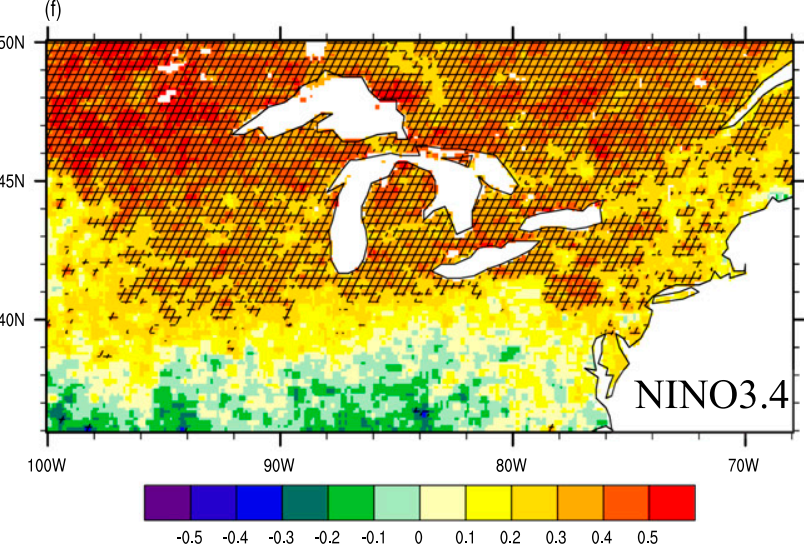

FIG. 2. The correlation coefficients between the numbers of winter (left) warm days and (right) warm nights and the (a),(b) NAO; (c),(d) PNA; and (e),(f) Niño-3.4 indices.

is that during positive phases of NAO, PNA, and Niño3.4 , the seasonal means of daily maximum temperature are usually above average over most parts of the region, especially the northern part, with clear skies. Under this condition, the diurnal turbulent mixing within the boundary layer will transfer energy to the higher-level atmosphere and therefore reduce the seasonal mean surface air temperature and finally reduce the possibility of occurrence of warm extremes through a shift in the PDFs. When comparing Figs. $2 \mathrm{c}$ and $2 \mathrm{~d}$ with Figs. $3 \mathrm{c}$ and $3 \mathrm{~d}$, it can be found that PNA has positive correlations with both warm extremes and cold extremes over part of the mid-Atlantic region, indicating a nonlinearity in the responses of the climate extremes to the PNA 


\section{Number of cold days}

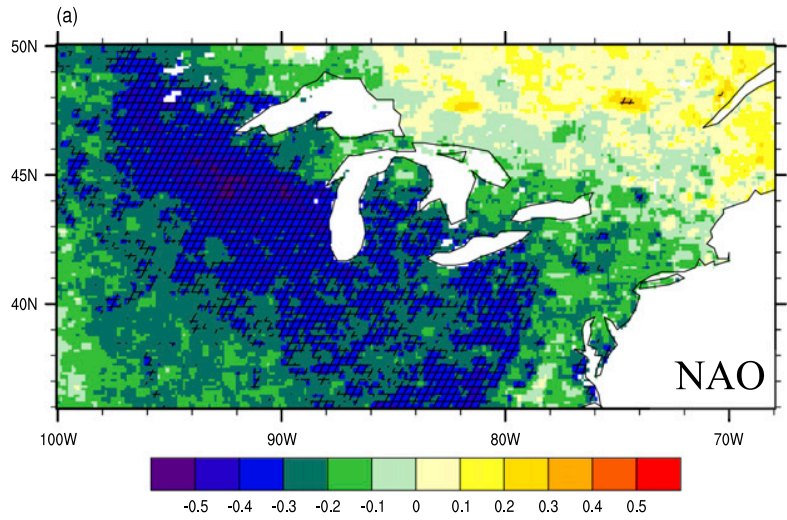

(c)
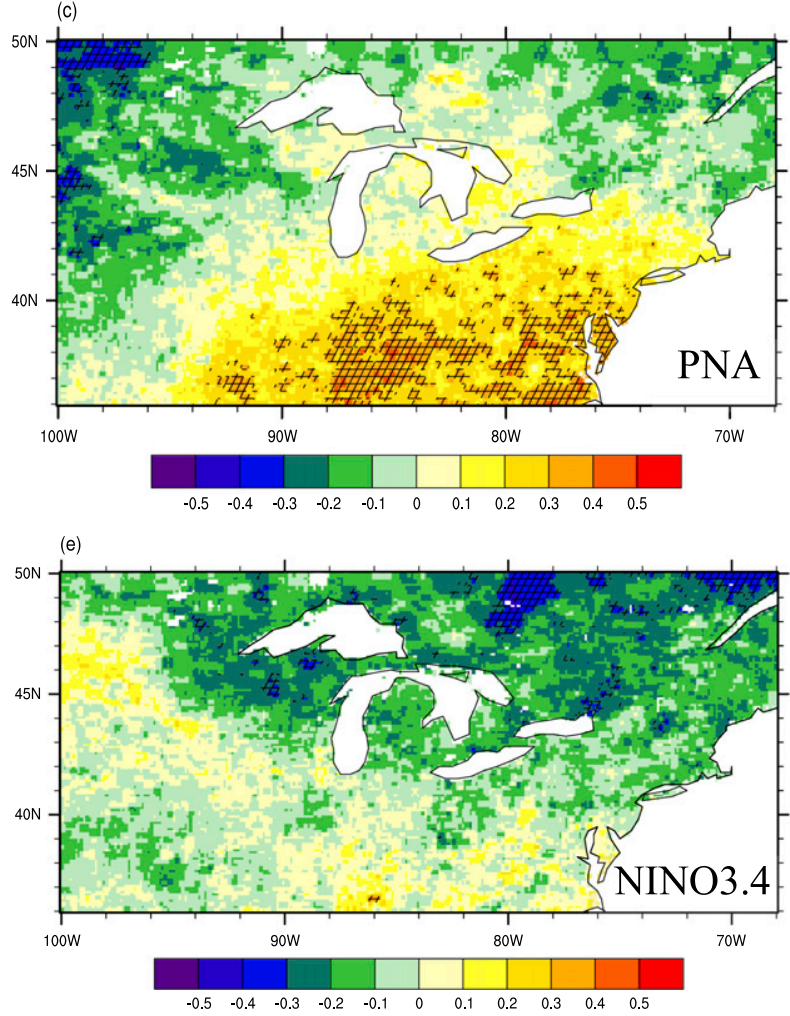

Number of cold nights

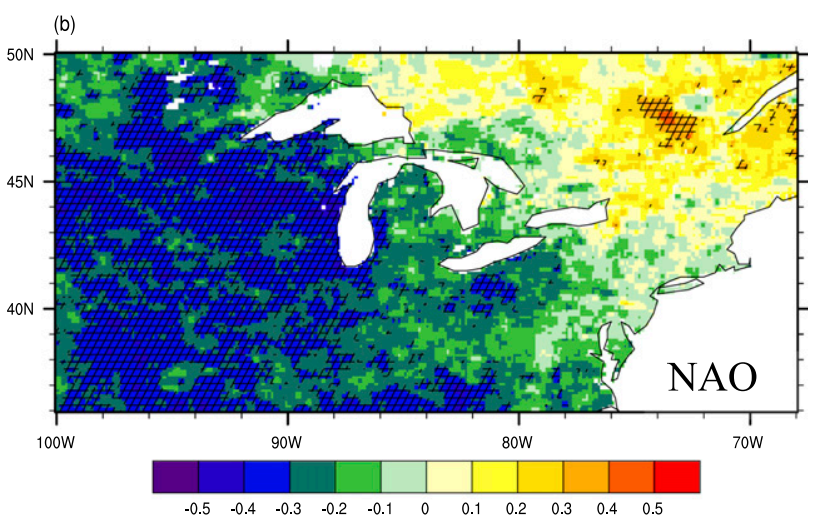

(d)

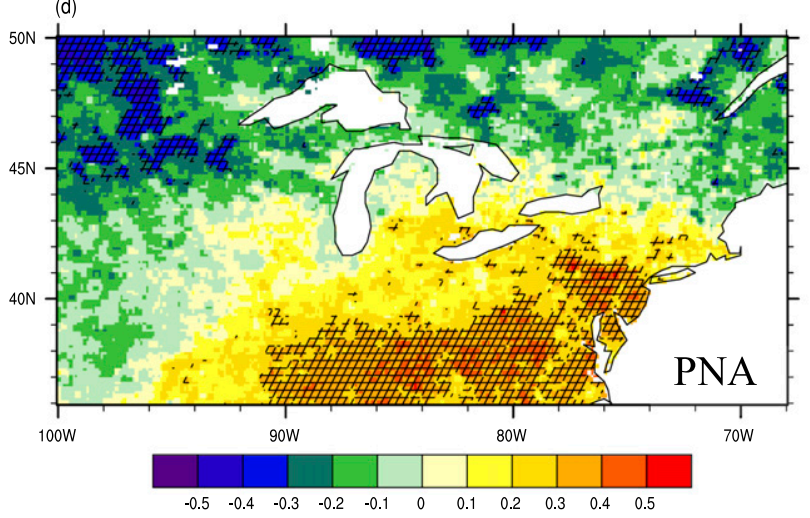

(f)

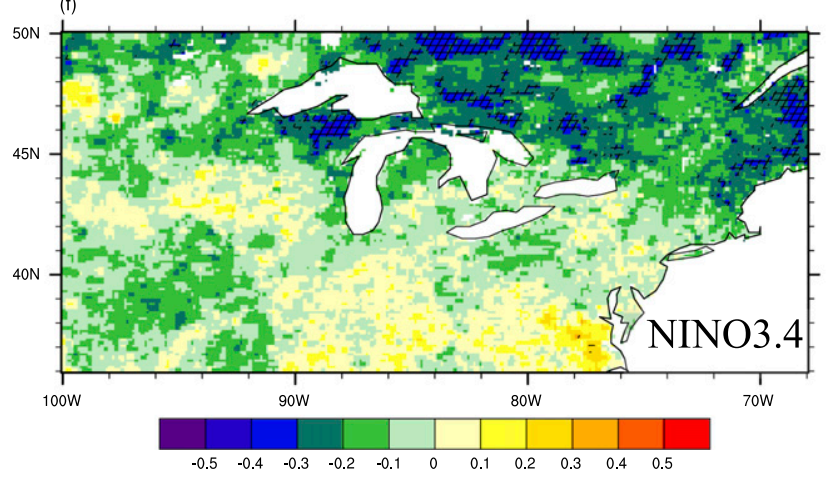

FIG. 3. As in Fig. 2, but for numbers of winter (left) cold days and (right) cold nights.

circulation pattern. One potential reason for this pattern is that the 50-yr time period is short, so the sample size may be too small. Another potential reason is that PNA time series show interdecadal variability, shifting from predominately negative values in the first half of the period to predominately positive values in the second half of the period (cf. Fig. 8b, described in greater detail below) introducing an aliasing effect over the whole time period. However, these mechanisms are only speculations, and the real mechanisms need further investigation.
The correlation patterns between the NAO, PNA, and ENSO indices and maximum and minimum values of winter daily Tmax and Tmin (see Figs. S1 and S2 in the supplemental material), which indicate the warmest and coldest, are similar to the patterns shown in Figs. 1-3. Among the temperature extremes, the patterns of maximum and minimum values of daily maximum temperature and minimum temperature are less obvious than the mean values (Fig. 1), indicating that the maximum and minimum values are not as sensitive to the large-scale climate variability as the mean values. 
The correlations between climate extremes related to daily precipitation and large-scale climate variability are not as significant and uniform as those related to daily temperature extremes. NAO has negative correlations with the number of days with daily precipitation larger than $10 \mathrm{~mm}$ over the northern part of the region and positive correlations over the southwestern part (Fig. 4a). The correlations between precipitation extremes and PNA and Niño-3.4 indices show a similar pattern: negative correlations to the north, especially around the Great Lakes and in a southwestnortheast zone west of the Appalachians (centered in the Ohio River valley), and positive correlations over the coastal region and western parts of this region (Figs. 4b,c).

These two patterns vary in intensity across all the other three indices representing precipitation extremes but generally maintain the same spatial signature for each of the circulation indices (see Figs. 5 and 6). For the number and total amount of extreme precipitation events (Fig. 5), the spatial patterns are usually similar for these two indices. There are negative correlations between the NAO and the two indices over the northern part of the region and positive correlations to the southwest and southeast (Figs. 5a,b). PNA has positive correlations with the two indices over the western part of the region, significant negative correlations over the Ohio valley, and positive correlations over the coastal region (Figs. 5c,d). The spatial patterns of the Niño-3.4 index are similar to the PNA patterns, with more significant positive correlations over the western part but less significant negative correlations over the Ohio valley. For maximum total precipitation over 5 continuous days, the spatial patterns are mainly similar to those of the extreme precipitation events. The only differences are that the positive correlation of NAO extends to more regions (Fig. 6a), and the negative correlations of PNA and Niño-3.4 over the Ohio valley are less significant (Figs. 6b,c).

The spatial patterns of the correlations of the number of consecutive dry days are generally the inverse of those patterns of the other four precipitation extremes (Fig. 7). NAO has a negative correlation with the number of consecutive dry days over the southwestern part of the region and a positive correlation over the northwestern part of the region and southeast of the Great Lakes (Fig. 7a). PNA mainly has a positive correlation with the number of consecutive dry days over the whole domain, with a significant correlation around the Great Lakes (Fig. 7b). The spatial pattern of Niño-3.4 is similar to the PNA pattern, with a positive correlation more concentrated around the Great Lakes and a larger area with negative correlations to the west (Fig. 7c).

\section{b. Dynamics behind the correlations}

Previous studies (e.g., Mearns et al. 1984; Wigley 1985; Wettstein and Mearns 2002) have shown that, because the relationships between the means of climate variables (i.e., maximum and minimum temperatures and precipitation) and the corresponding extremes are nonlinear, small changes in the means of climate variables can result in large changes in both the intensity and frequency of climate extremes. Therefore, in this section, a composite analysis calculating the differences in seasonal average circulation fields between high- and low-index winters, was used to investigate the physical mechanisms behind the relationships between winter mean maximum and minimum temperatures and precipitation and seasonal mean circulation patterns under different phases of the three large-scale patterns of climate variability. Then, in the next section, the responses of daily maximum temperature, minimum temperature, and precipitation to the changes of winter mean maximum temperature, minimum temperature, and precipitation were examined through the changes in probability distributions. These analyses reveal that when the three largescale patterns of climate variability are in positive or negative phases, the climate extremes are (or are not) likely to occur, because of the changes in winter mean maximum and minimum temperatures and precipitation brought by changes in seasonal large-scale circulation patterns.

Figure 8 shows the standardized time series of the observed winter NAO, PNA, and Niño-3.4 indices. Substantial variability is seen on both interannual and interdecadal time scales. High- and low-index winters for all indices were defined as anomalies exceeding plus or minus one standard deviation from the long-term mean (Table 2). The differences of monthly average geopotential height, wind field, SLP, and low-level moisture flux between the winters with the high and low indices were then calculated. A Student's $t$ test was applied to the differences to determine whether the differences are significant.

\section{1) $\mathrm{NAO}$}

One important factor influencing temperature changes over a large area is the advection term. To explain the correlations between winter temperature extremes and the NAO index, the SLP differences between high- and low-NAO winters are given in Fig. 9a. During positiveNAO winters, prevailing southerly wind anomalies at a low level (Fig. 9b) because of the east-west SLP gradient (Fig. 9a) bring warm air into this region, so there are positive temperature anomalies over the northeastern United States and higher winter mean maximum and minimum temperatures. These southerly wind anomalies are also shown when comparing the wind anomalies 
Number of days with precipitation larger than $10 \mathrm{~mm}$

(a)

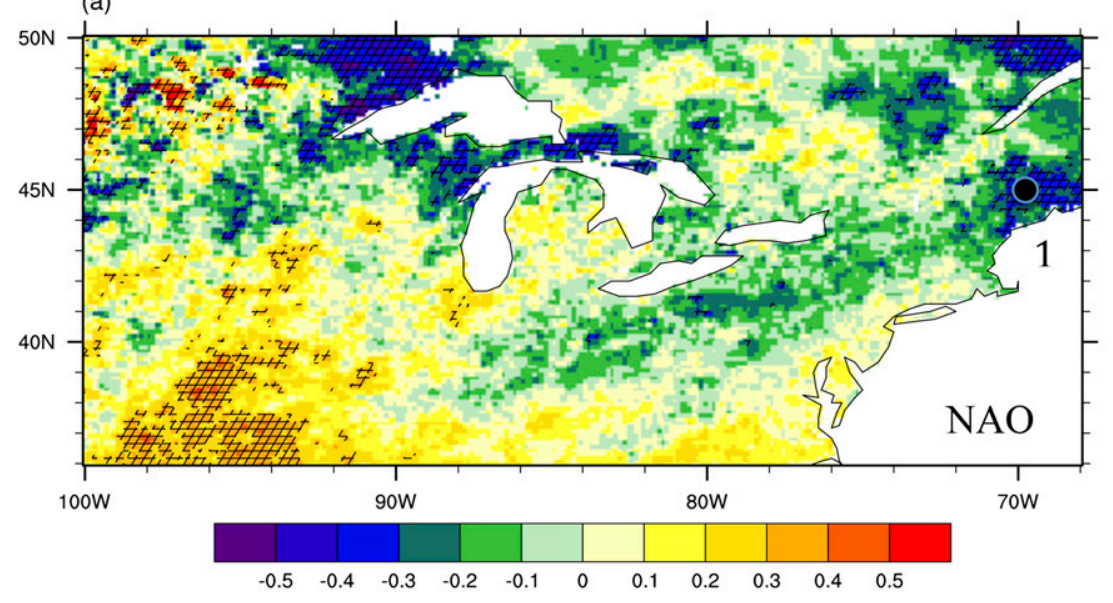

(b)

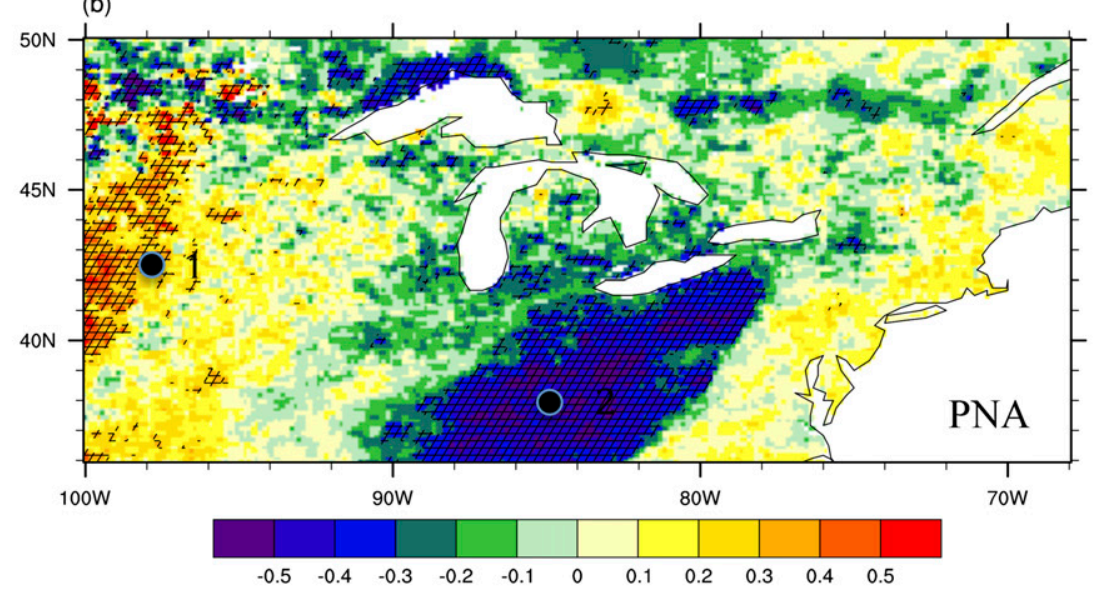

(c)

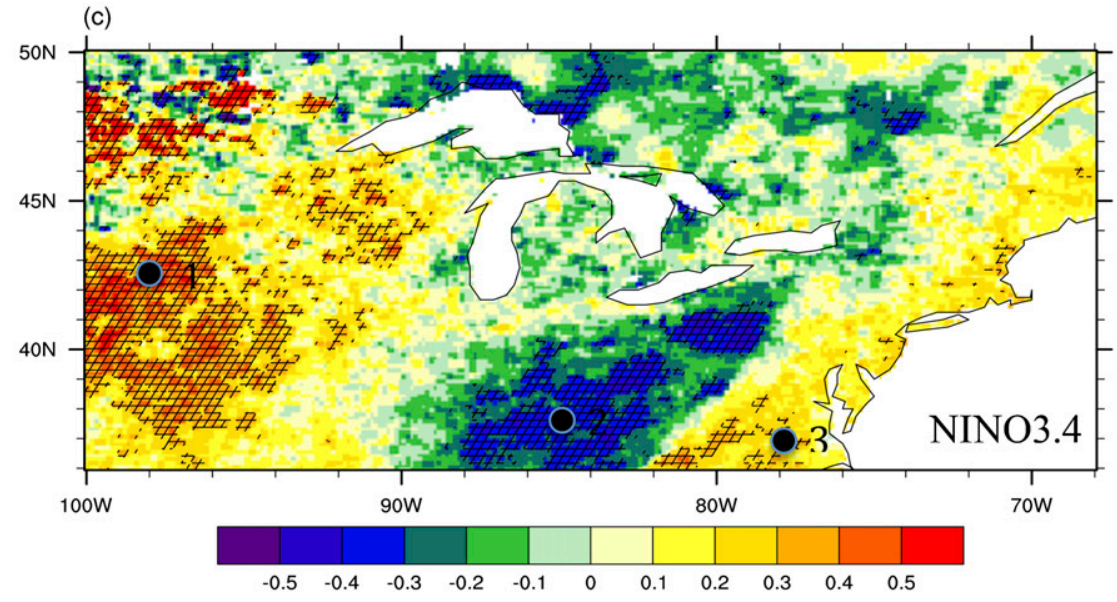

FIG. 4. The correlation coefficients between the number of days with daily precipitation larger than $10 \mathrm{~mm}$ and the (a) NAO, (b) PNA, and (c) Niño-3.4 indices. The dots indicate the locations used in the CDF calculation in Fig. 13. 


\section{Number of extreme precipitation events}
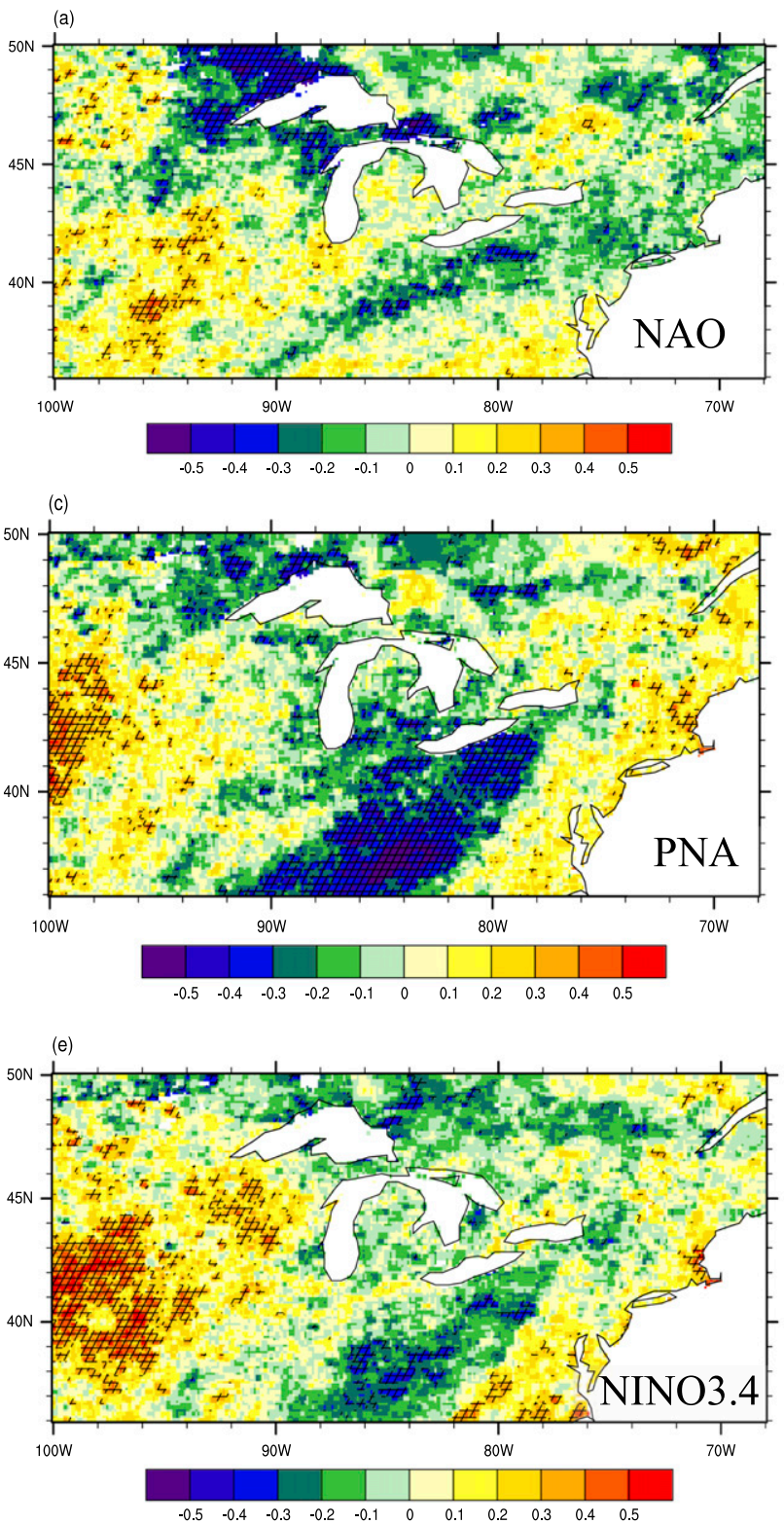

\section{Total extreme precipitation amount}
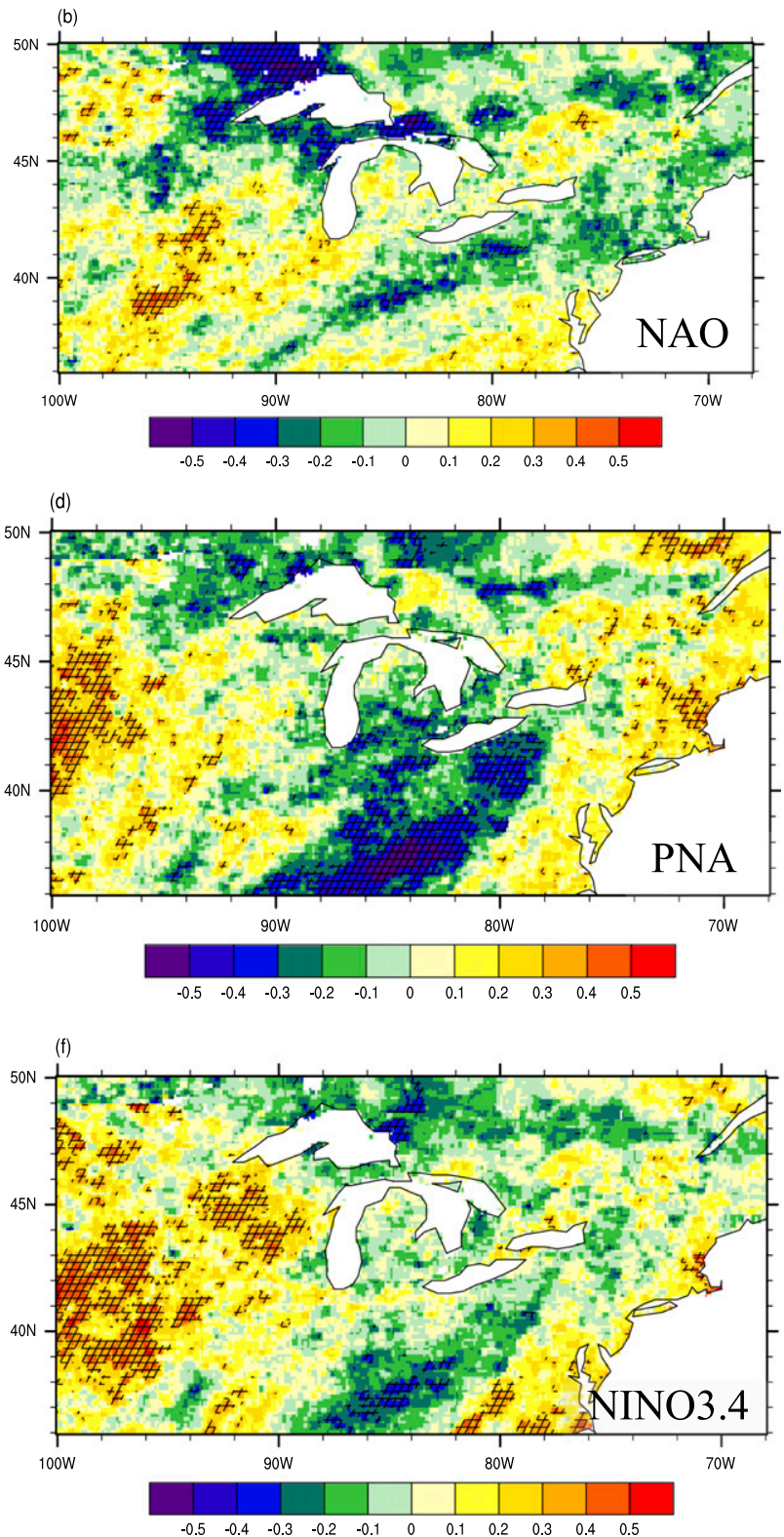

FIG. 5. The correlation coefficients between the (left) number and (right) total amount of winter extreme precipitation events and the (a),(b) NAO; (c),(d) PNA; and (e),(f) Niño-3.4 indices.

during the winters with high-NAO indices and low-NAO indices (see Fig. S3 in the supplemental material).

More importantly, during positive-NAO years, at the 300-hPa level, there are significant positive geopotential height anomalies over the northeastern United States (Fig. 9c), implying blocking of cold air from entering this region. On the other hand, negative-NAO conditions are associated with deepening (Yarnal and Leathers 1988; Notaro et al.2006) and western shift of the regional trough axis (Bradbury et al. 2002b) over the eastern United
States, which cause more polar air invasions and colder temperatures. An extension of the Bermuda/Azores high to the northeastern United States (Fig. 9a) also blocks midlatitude storms from entering this region, leading to reduced storm-related precipitation.

\section{2) PNA}

The differences in the 300-hPa geopotential height field between high- and low-PNA winters (Fig. 10a) show that, 


\section{Maximum 5-day precipitation total}

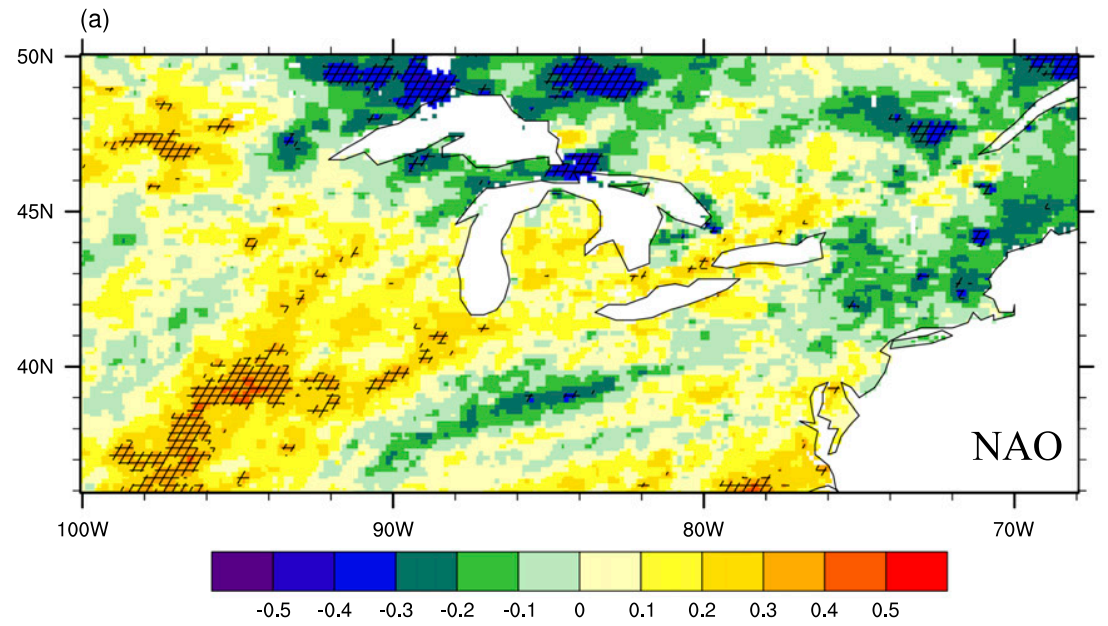

(b)

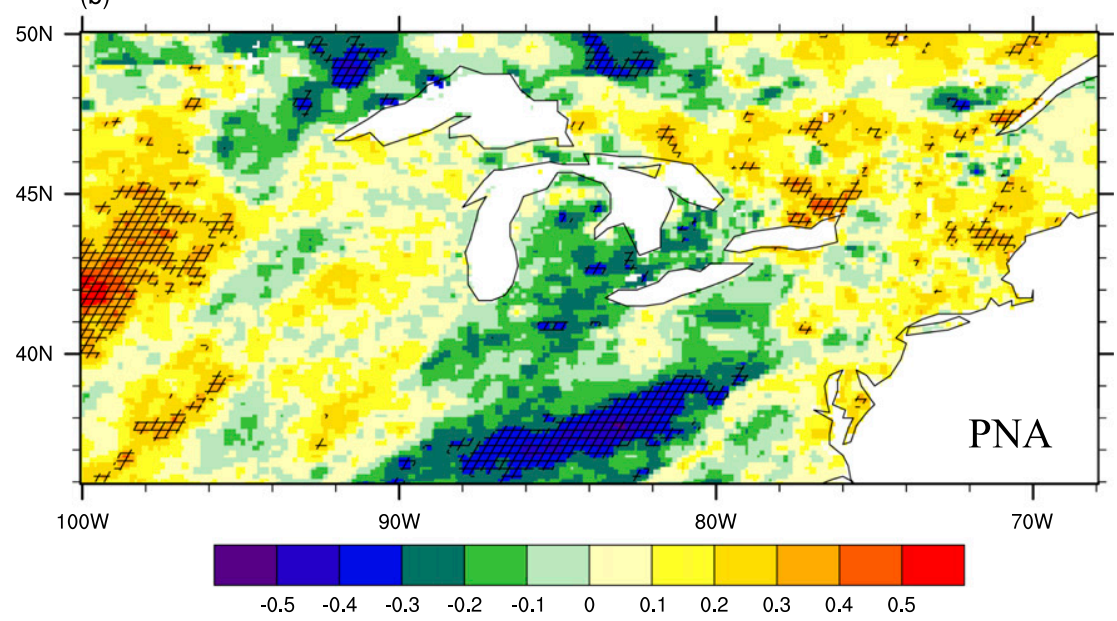

(c)

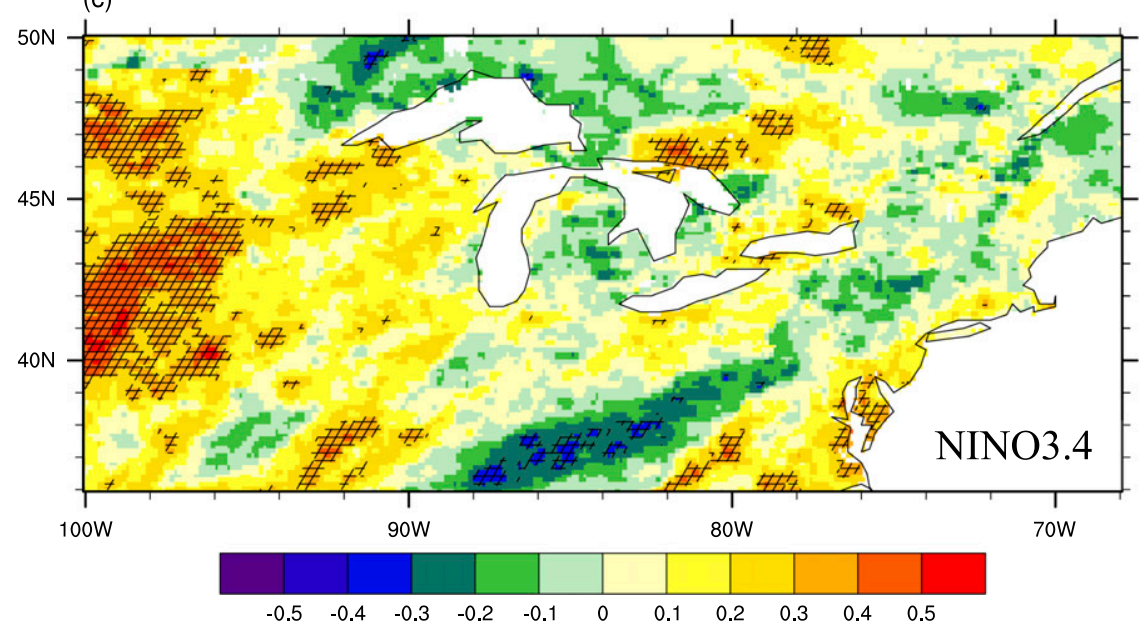

FIG. 6. The correlation coefficients between the max total precipitation amount of 5 continuous days and the (a) NAO, (b) PNA, and (c) Niño-3.4 indices. 
Maximum number of consecutive dry days

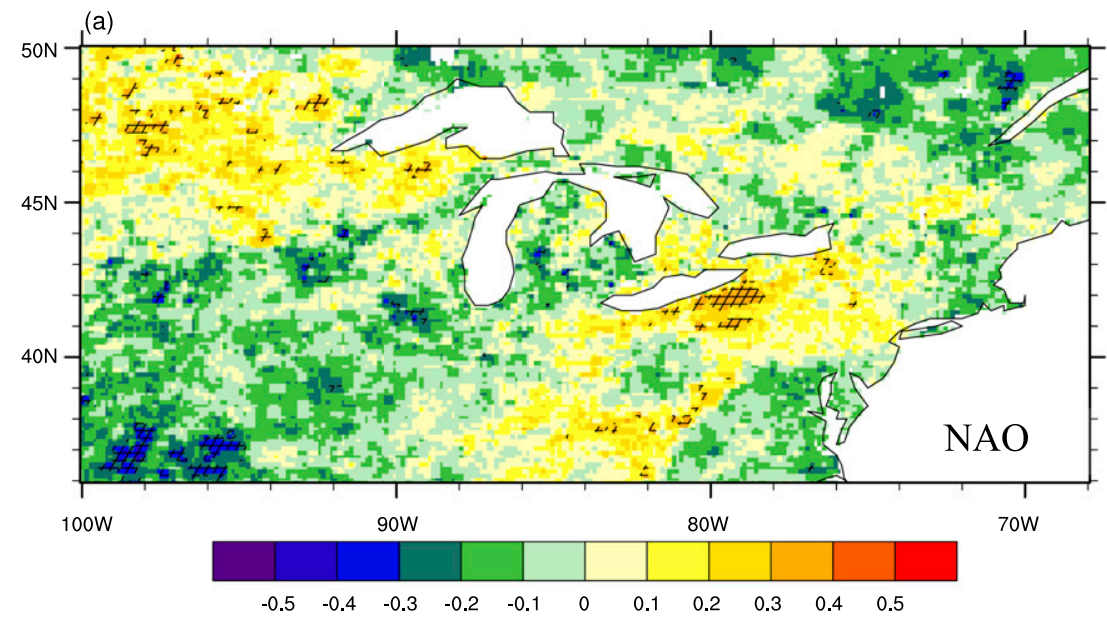

(b)

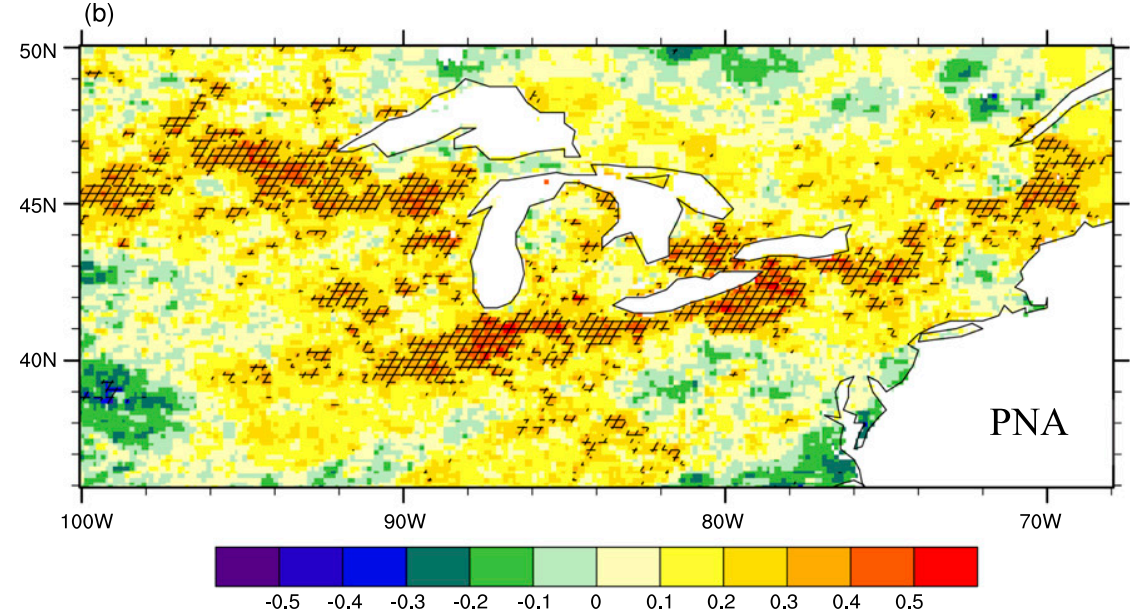

(c)

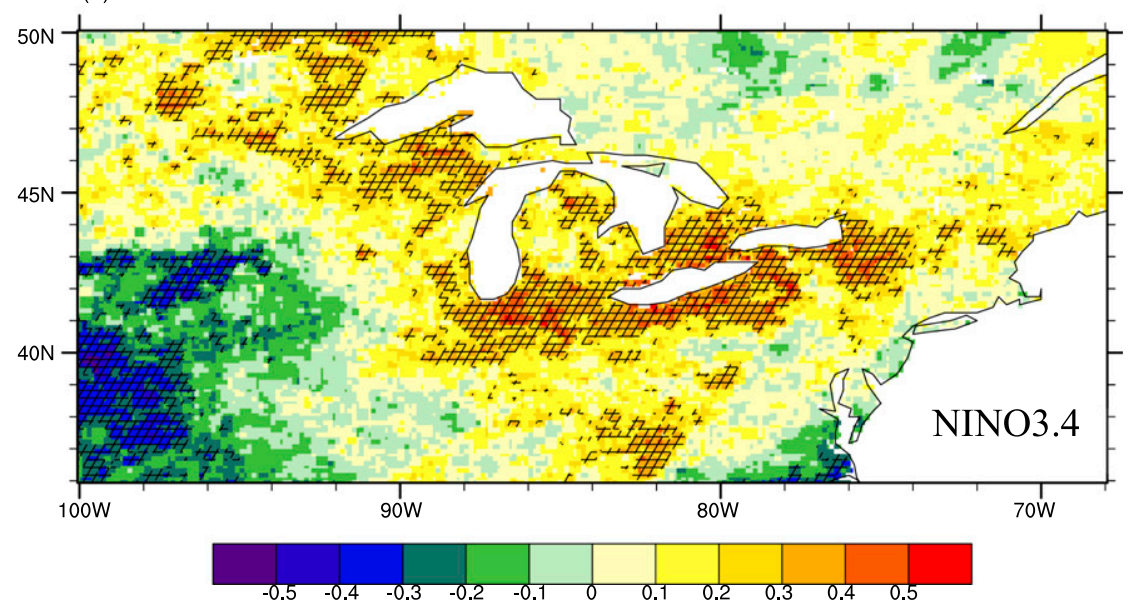

FIG. 7. As in Fig. 6, but for the max number of consecutive dry days. 

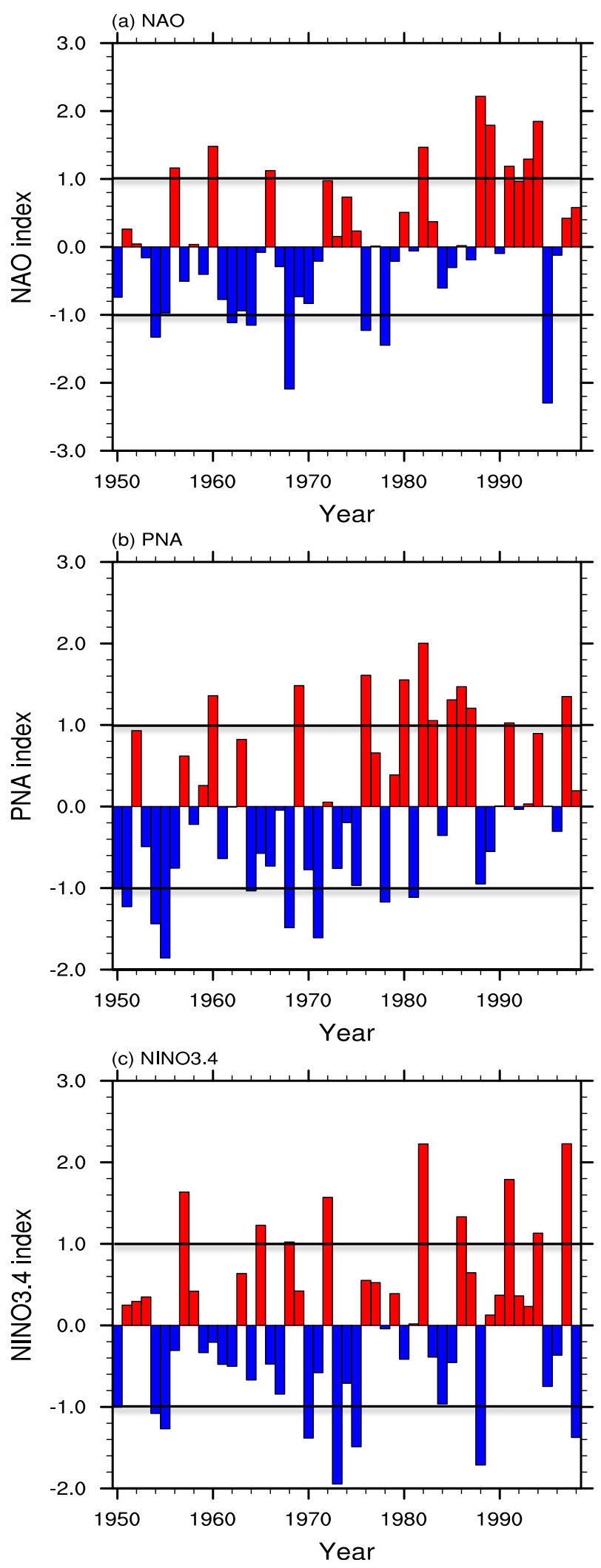

FIG. 8. The standardized (a) NAO, (b) PNA, and (c) Niño-3.4 indices for the 1950/51-1998/99 winters. The lines indicate the plus or minus one std dev from the long-term mean. during high-PNA condition, positive geopotential height anomalies over the northwestern United States displace this deeper trough of the polar jet stream over the northeastern United States southeastward (see Fig. S4 in the supplemental material), as shown in Notaro et al. (2006). The corresponding wind anomalies at $850 \mathrm{hPa}$ (Fig. 10b) show that, under high-PNA condition, the circulation pattern allows polar air masses to intrude into the southcentral United States and northeastern Canada, but the wind anomalies over the northern part of the study region are not obvious because of the counteraction from the cyclonic circulation over the southeastern United States. Moreover, this cyclonic circulation over the southeastern United States also brings cold air from the U.S. Northeast (Fig. 10b). Therefore, there are negative temperature anomalies over the southern part of the northeastern United States and, thus, below-average winter mean temperature in this area during high-PNA winters. But over the large northern part of our region, there are positive temperature anomalies and also higher mean temperatures.

To explain the relationships between winter precipitation and the PNA index, the low-level moisture flux difference between high- and low-PNA winters is shown in Fig. 10c. Usually, intense moisture flux brings high winter precipitation, while moisture deficit is always associated with winter drought (Dominguez and Kumar 2005). Previous studies (e.g., Leathers et al. 1991; Coleman and Rogers 2003) also show that the influences of the PNA mode on regional winter precipitation are mainly achieved through moisture flux convergence. During high-PNA years, over the western part of the region, there is strong moisture flux from the west, and this above-normal moisture induces more winter precipitation and enhances the possibilities of heavy precipitation. However, anticyclonic circulation over the southeastern United States prevents moisture from the Gulf of Mexico entering the Ohio River valley region, reducing winter precipitation and corresponding occurrences of extreme precipitation there during high-PNA winters.

This study mainly focuses on the moisture flux due to seasonal mean circulation; however, we note that moisture flux due to transient eddies over certain regions can be comparable to the moisture flux due to the seasonal mean circulation (Peixoto and Oort 1992).

\section{3) NIÑO-3.4}

The PNA and Niño-3.4 indices are significantly correlated $(r=0.53, p<0.01)$; however, the years used for composite analysis for PNA and ENSO are not the same, indicating the PNA response to the ENSO is not linear. Therefore, there are differences between the synoptic circulation patterns during high-Niño-3.4 
TABLE 2. Extreme years selected for circulation pattern anomaly analysis (anomalies exceeding plus or minus one std dev from the long-term mean).

\begin{tabular}{ll}
\hline \hline \multicolumn{1}{c}{ Index } & \multicolumn{1}{c}{ Years } \\
\hline +NAO & $1956 / 57,1960 / 61,1966 / 67,1982 / 83,1988 / 89,1989 / 90,1991 / 92,1993 / 94$, and $1994 / 95$ \\
-NAO & $1954 / 55,1962 / 63,1964 / 65,1968 / 69,1976 / 77,1978 / 79$, and $1995 / 96$ \\
+PNA & $1969 / 70,1976 / 77,1980 / 81,1982 / 83,1983 / 84,1985 / 86,1986 / 87,1987 / 88,1991 / 92$, and $1997 / 98$ \\
-PNA & $1951 / 52,1954 / 55,1955 / 56,1964 / 65,1968 / 69,1971 / 72,1978 / 79$, and $1981 / 82$ \\
+Niño-3.4 & $1957 / 58,1965 / 66,1968 / 69,1972 / 73,1982 / 83,1986 / 87,1991 / 92,1994 / 95$, and $1997 / 98$ \\
-Niño-3.4 & $1950 / 51,1954 / 55,1955 / 56,1970 / 71,1973 / 74,1975 / 76,1988 / 89$, and $1998 / 99$ \\
\hline
\end{tabular}

winters and those during high-PNA winters, although there are still some similarities, as indicated by Loikith and Broccoli (2014). One major difference is that during high-Niño-3.4 winters, the placement of positive geopotential height over North America extends to the east, showing a wave- 1 pattern (Straus and Shukla 2002) (Fig. 11a). Therefore, the correlations between winter temperature extremes and the Niño-3.4 index are similar to those correlations with the PNA index, but the patterns over the northern part of the northeastern United States extend to the east because of temperature advection (Fig. 11b). The low-level moisture flux differences between high- and low-Niño-3.4 winters are also similar to the differences between high- and low-PNA winters (cf. Figs. 10c and 11c), so the correlations between winter precipitation extremes and the Niño-3.4 index over the western part of the northeastern United States and Ohio valley are similar to those of the PNA index. Another important aspect is that during strong El Niño winters, there are more winter storms generated from the Gulf of Mexico moving northward (Frankoski and DeGaetano 2011), resulting in significant negative pressure anomalies over the coast, from the Gulf of Mexico to the North Atlantic region (Fig. 11d), and these winter storms bring increased winter precipitation over the coastal region of the northeastern United States.

\section{c. Responses of daily variables}

To examine the responses of daily scale climate extremes to the differences of winter mean maximum temperature, minimum temperature, and precipitation influenced by the large-scale modes of climate variability discussed in the previous sections, changes in probability distributions of daily maximum and minimum temperatures and precipitation due to the differences of seasonal mean maximum and minimum temperatures and precipitation are investigated in this section.

Figure 12 compares probability distributions of the daily maximum temperature (Figs. 12a,c,e) and minimum temperature (Figs. 12b,d,f) during the winters with high- and low-NAO indices (Figs. 12a,b), high- and
low-PNA indices (Figs. 12c,d), and high- and low-Niño-3.4 indices (Figs. 12e,f). To capture the prevailing relationships, the probability distributions are calculated over three locations within the centers of large correlation values shown as triangles in Figs. 1a, 1c, and 1e. From Fig. 12, it can be concluded that during the winters with high indices (blue lines), both the probability distributions of daily maximum temperature and minimum temperature shift to the right side compared with those during the winters with low indices (red lines), indicating larger probabilities of days with higher temperature and smaller probabilities of days with lower temperature. Moreover, the average values of daily maximum and minimum temperatures during the winters with high indices are significantly larger than those under low indices when a Student's $t$ test is applied, while the widths of the probability distributions (defined as the differences between $75 \%$ and $25 \%$ threshold values) do not differ too much. The probability distributions thus demonstrate that during the winters with high indices, there are more warm extremes and fewer cold extremes.

Figure 13 shows a similar comparison for daily precipitation. In this analysis, since the correlations are not spatially homogeneous, two locations are selected for the PNA case, and three locations are selected for the Niño-3.4 case to capture the different responses over different regions; these locations are shown in Fig. 4. To clearly show the details of the probabilities over the large daily precipitation values, cumulative distribution functions (CDFs) rather than probability distributions are shown here, and all the days without precipitation are removed. During winters with high-NAO indices, the CDF shifts to the left side with a larger probability of smaller daily precipitation values, and the corresponding average value is smaller (Fig. 13a), indicating a lower probability of extreme precipitation events. During winters with high-PNA indices, the CDF over the western part of the northeastern United States shifts to the right with larger averages (Fig. 13b), while the CDF over the Ohio valley shifts to the left side with smaller averages (Fig. 13c), indicating corresponding larger probabilities of extreme precipitation events over the western part but 
(a)

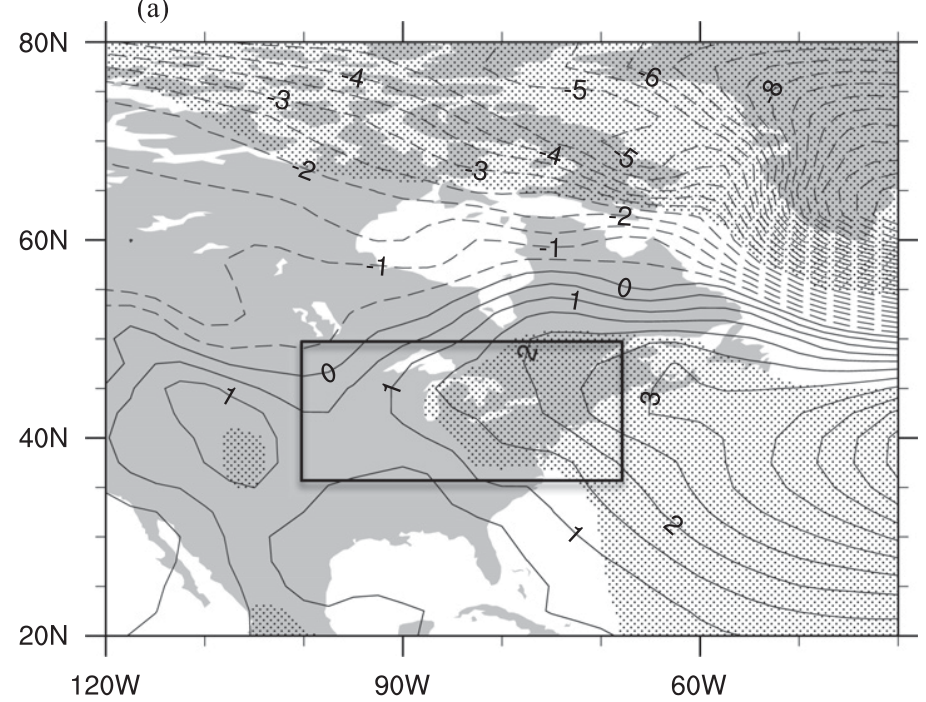

(b)

Unit: $\mathrm{m} / \mathrm{s}$

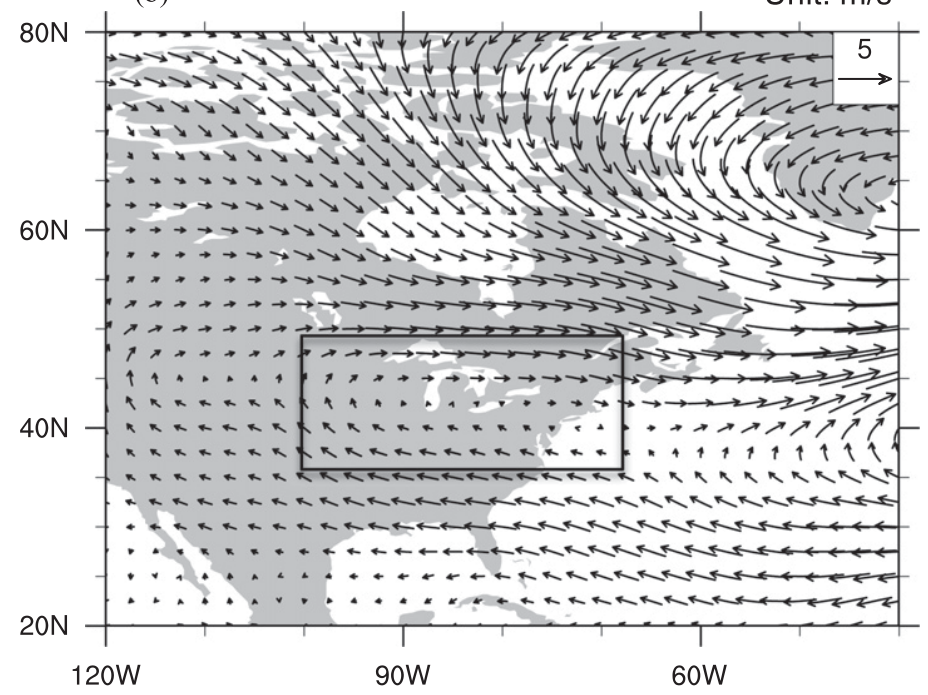

(c)

Unit: $m$

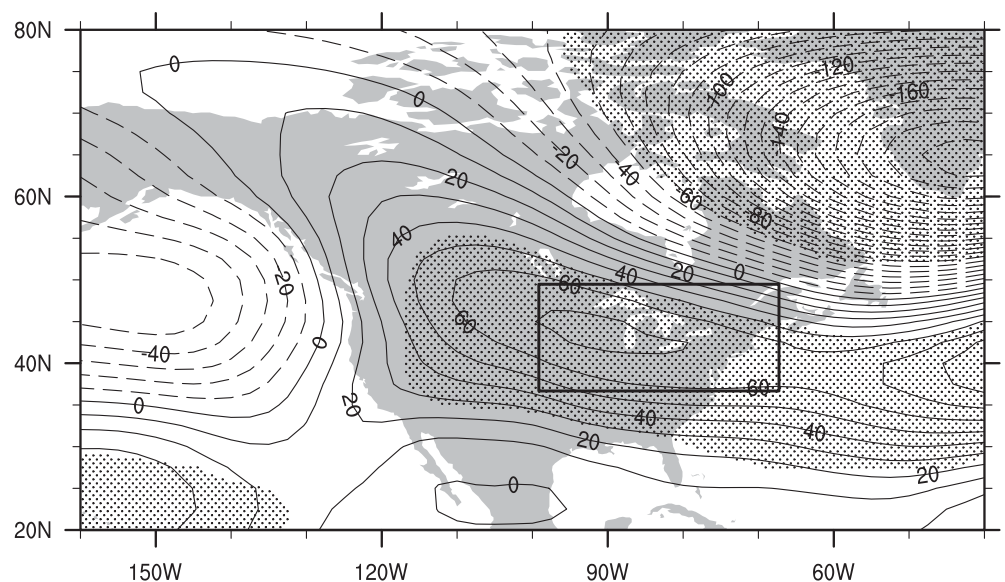

FIG. 9. The differences of (a) SLP field (hPa), (b) 850-hPa wind field $\left(\mathrm{m} \mathrm{s}^{-1}\right)$, and (c) 300-hPa geopotential height field $(\mathrm{m})$ between the winters with high- and lowNAO indices. The stippling indicates differences significant at the $p=0.05$ level. The rectangle indicates the study region. 
(a)

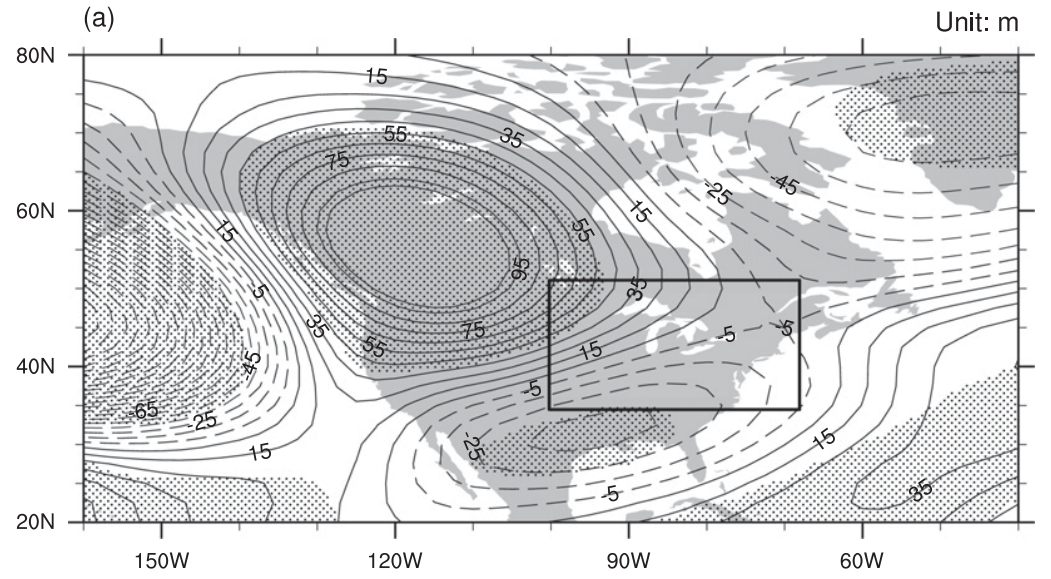

(b)

Unit: $\mathrm{m} / \mathrm{s}$

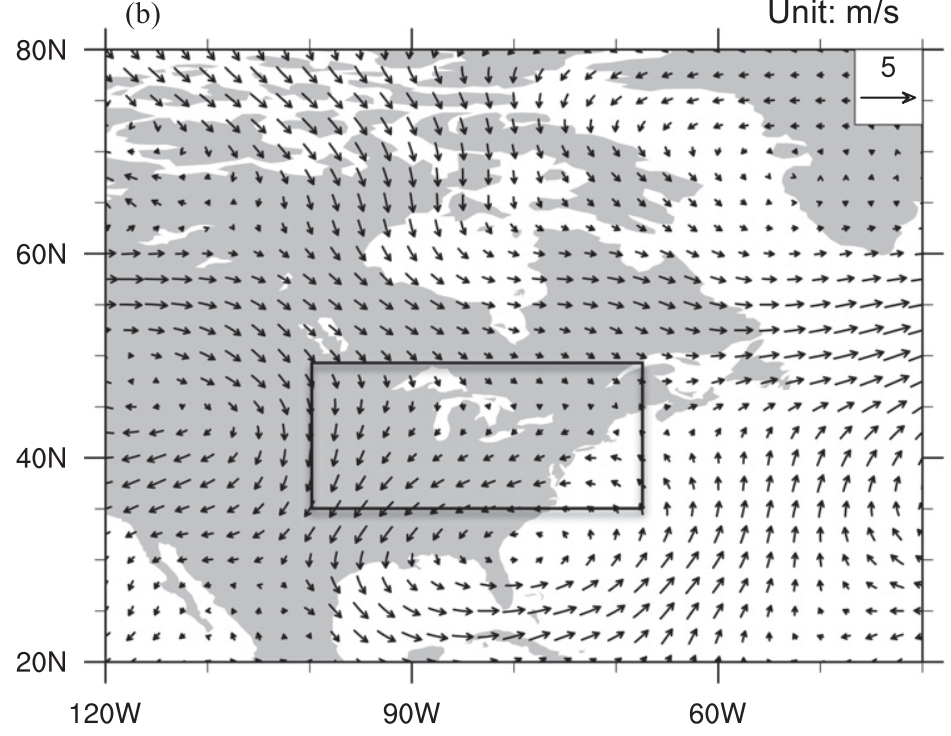

(c)

Unit: $\mathrm{kg} / \mathrm{m}^{*} \mathrm{~s}$

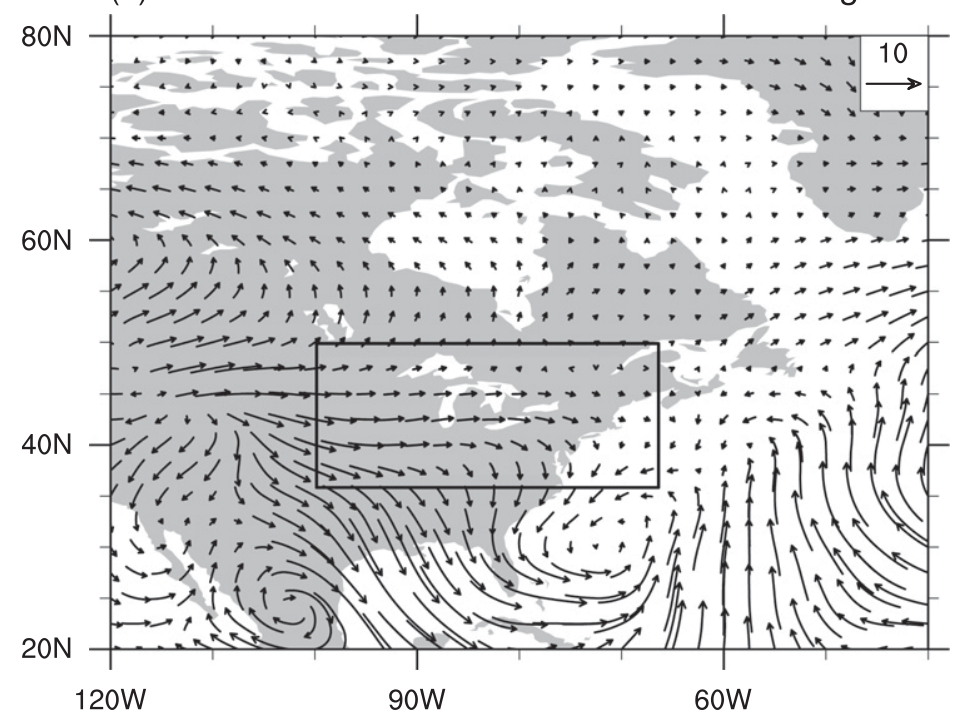

FIG. 10. The differences of (a) 300-hPa geopotential height field (m), (b) 850-hPa wind field $\left(\mathrm{m} \mathrm{s}^{-1}\right)$, and (c) low-level moisture flux $\left[\mathrm{kg}(\mathrm{m} \mathrm{s})^{-1}\right]$ between the winters with high- and low-PNA indices. 

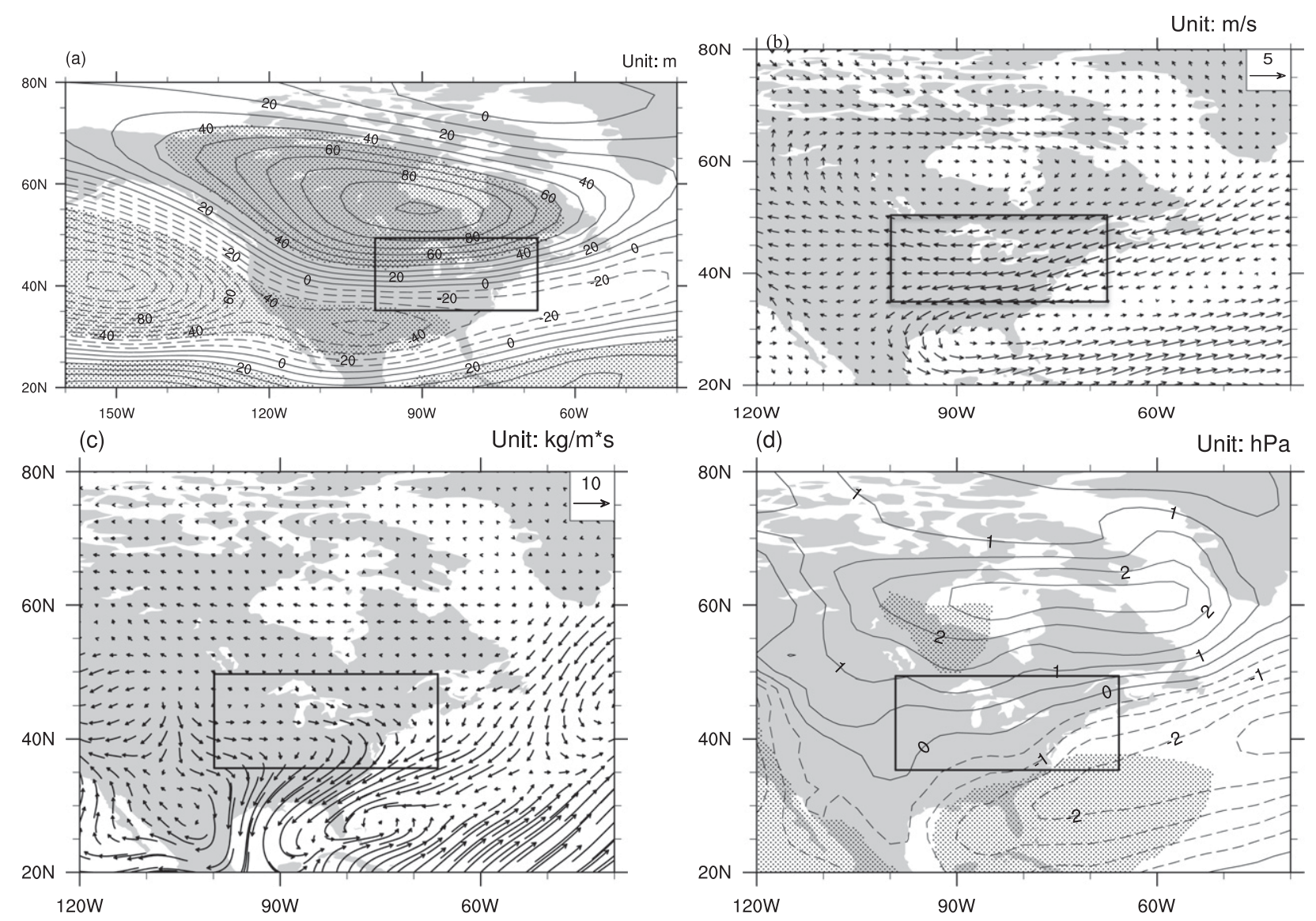

FIG. 11. The differences of (a) 300-hPa geopotential height (m), (b) 850-hPa wind field ( $\mathrm{m} \mathrm{s}^{-1}$ ), (c) low-level moisture flux [kg (m s) $\left.{ }^{-1}\right]$, and (d) SLP (hPa) between the winters with high- and low-Niño-3.4 indices.

smaller probabilities of extreme precipitation events over the Ohio valley. For the Niño-3.4 index, the CDFs over the western part (Fig. 13d) and Ohio valley (Fig. 13e) are similar to those of PNA conditions, and the CDF over the coastal region during winters with high-Niño-3.4 indices shifts to the right side with larger averages (Fig. 13f), indicating larger probabilities of extreme precipitation events. These shifts of CDFs show that the responses of daily precipitation values over different regions to largescale modes of climate variability result in the correlation patterns discussed in the previous sections.

\section{Conclusions}

Teleconnections between 15 winter climate extremes that are highly relevant to regional hydrology, ecosystems, and energy usage over the northeastern United States and adjacent parts of Canada were analyzed in relation to three major patterns of large-scale climate variability. The corresponding physical mechanisms for the anomalies were then examined.
The NAO index usually has significant positive relations with warm-temperature extremes and negative relations with cold-temperature extremes over most of the region, because during high-NAO winters, the Bermuda/Azores high extends to the northeastern United States, so this positive pressure anomaly blocks the polar jet stream from entering this region, and the east-west pressure gradient induces southerly wind anomalies, leading to positive temperature anomalies. These positive temperature anomalies result in significant shifts to the right side on the probability distributions of daily maximum temperature and minimum temperature, indicating larger probabilities of warm extremes and smaller probabilities of cold extremes.

Moreover, the positive SLP anomalies during highNAO winters over the northern part of this region (due to the Bermuda/Azores high extension) block midlatitude winter storms and, thus, reduce the amount of seasonal mean precipitation, shifting the CDFs of daily precipitation to the left side. Therefore, the NAO index has negative correlations with the precipitation 

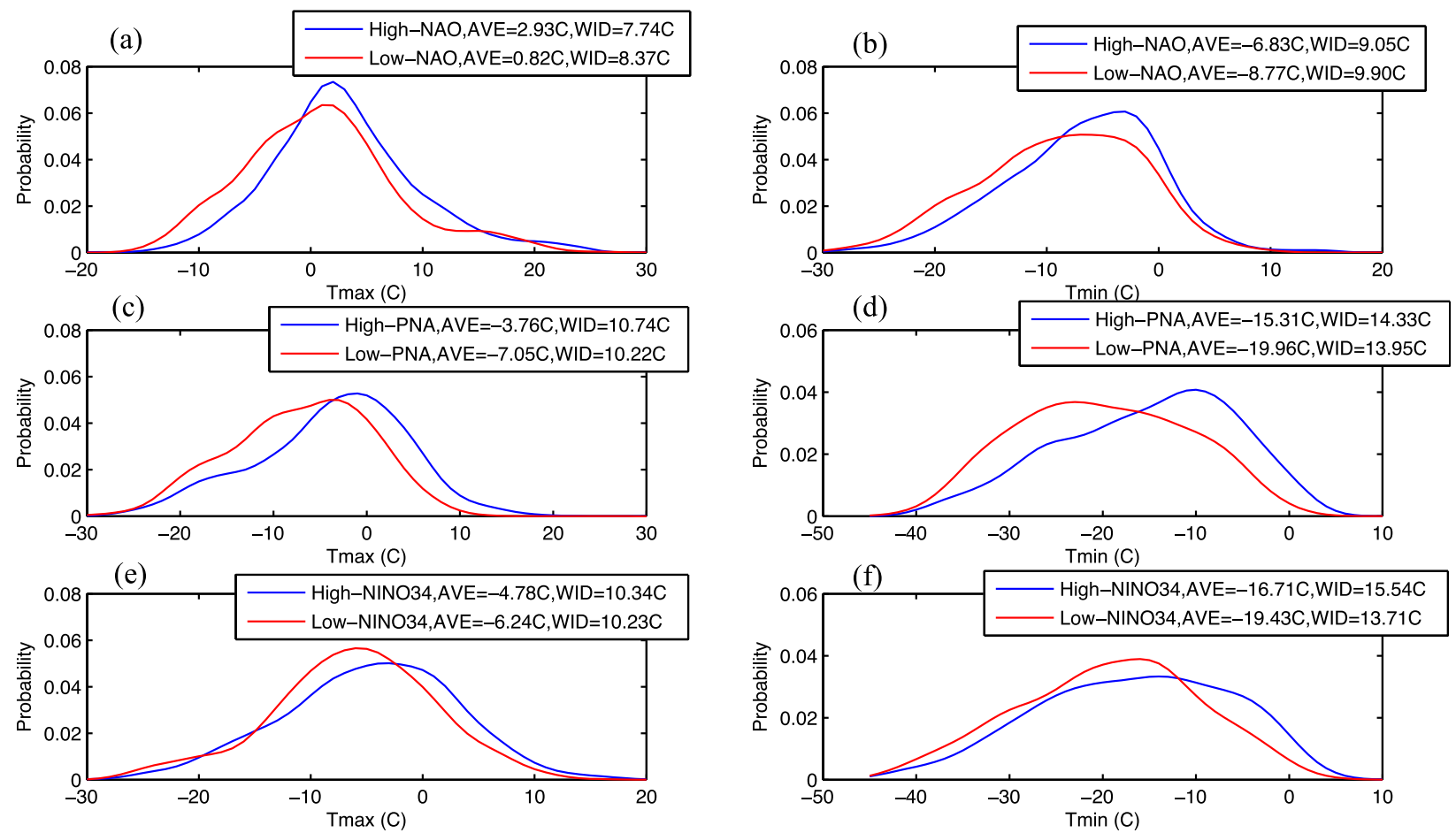

FIG. 12. The comparisons of probability distributions of daily (left) max temperature and (right) min temperature between the winters with (a),(b) high (blue)- and low (red)-NAO indices; (c),(d) high (blue)- and low (red)-PNA indices; and (e),(f) high (blue)- and low (red)Niño-3.4 indices. Locations used for calculating the PDFs are shown in Fig. 1.

extremes over the northern part of the northeastern United States.

Both PNA and Niño-3.4 indices have similar patterns of prevailing significant positive correlations with the warm extremes over large parts of the region to the north and negative correlations to the south. The associated physical mechanism is that during high-PNA winters, positive geopotential height anomalies over North America displace the polar jet stream to the east so that there are positive temperature anomalies over the northern part of the northeastern United States, and the positive temperature anomalies make the probability distributions of daily maximum temperature and minimum temperature shift significantly to the right side, resulting in larger probabilities of warm extremes and smaller probabilities of cold extremes. The difference is that during positive Niño-3.4 winters, the positive geopotential anomaly extends more to the east, so the correlation patterns also extend to the east. The negative geopotential height anomalies induce northerly wind anomalies over the southern part of the region, inducing negative correlations with warm extremes.

The composite analysis of low-level moisture flux shows that during either high-PNA or high-Niño-3.4 winters, more moisture is transported to the western part of the region, but less moisture is transported into the Ohio River valley from the Gulf of Mexico, which results in more precipitation over the western part and less precipitation over the Ohio valley. Moreover, during highNiño-3.4 winters, there are more winter storms generated from the Gulf of Mexico moving north, and these winter storms bring more precipitation over the coastal region. The comparisons between the CDFs of daily precipitation values over different locations also confirm that the CDFs shift with the average values, indicating more precipitation extremes over the western part and fewer precipitation extremes over the Ohio valley during high-PNA and highNiño-3.4 winters and more precipitation over the coastal region during high-Niño-3.4 winters.

Acknowledgments. This research is based in part upon work supported by the Department of the Interior's Northeast Climate Science Center, under USGS funding G12AC00001. Edwin P. Maurer (Santa Clara University) kindly provided the observed daily precipitation, maximum temperature, and minimum temperature data. The NAO, PNA, Niño-3.4 time series, and the NCEP grid data were obtained from the National Centers for Environmental Prediction (NCEP). We would like to acknowledge high-performance computing support from Yellowstone (ark:/85065/d7wd3xhc) provided by NCAR's 
(a)

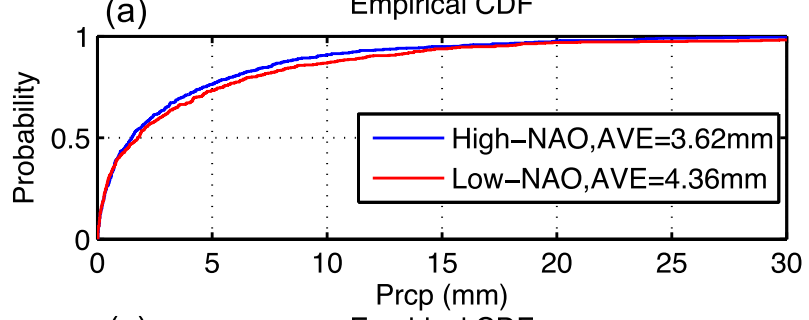

(c)

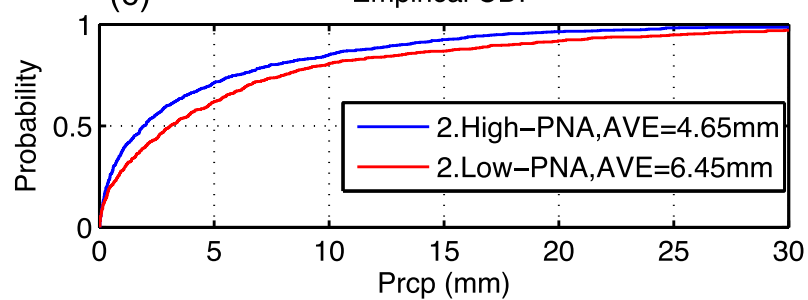

Empirical CDF

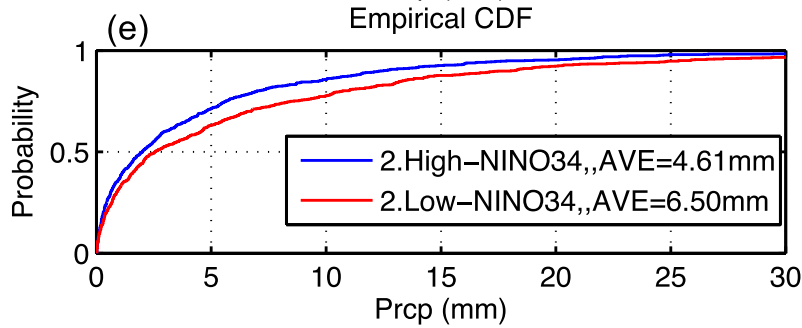

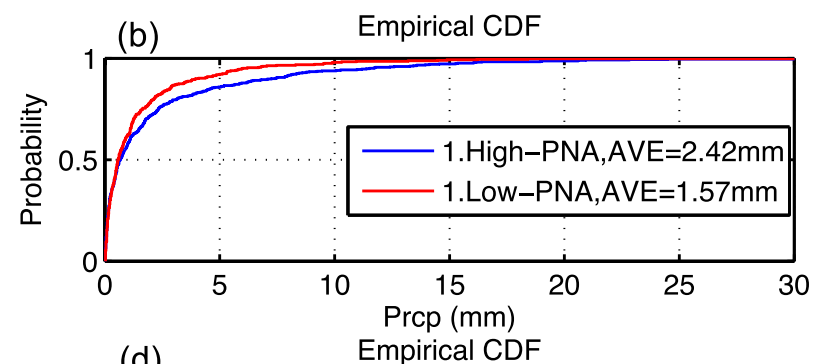
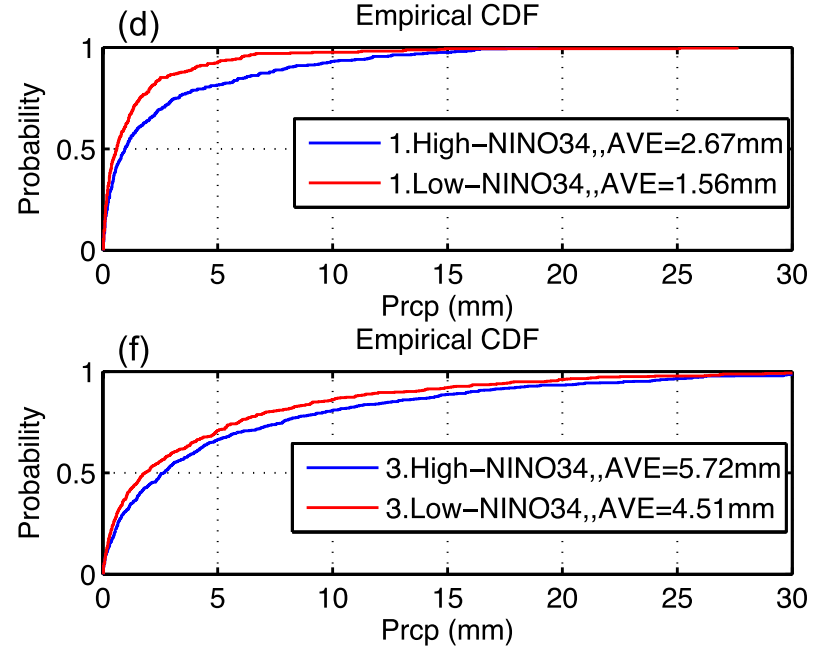

FIG. 13. The comparisons of cumulative distributions of daily precipitation between the winters with (a) high (blue)- and low (red)NAO indices; (b),(c) high (blue)- and low (red)-PNA indices, and (d)-(f) high (blue)- and low (red)-Niño-3.4 indices. Locations used for calculating the CDFs are shown in Fig. 4.

Computational and Information Systems Laboratory, sponsored by the National Science Foundation.

\section{REFERENCES}

Alexander, L. V., and Coauthors, 2006: Global observed changes in daily climate extremes of temperature and precipitation. J. Geophys. Res., 111, D05109, doi:10.1029/2005JD006290.

An, S.-I., J.-S. Kug, A. Timmermann, I.-S. Kang, and O. Timm, 2007: The influence of ENSO on the generation of decadal variability in the North Pacific. J. Climate, 20, 667-680, doi:10.1175/JCLI4017.1.

Barnston, A. G., and R. E. Livezey, 1987: Classification, seasonality, and persistence of low-frequency atmospheric circulation patterns. Mon. Wea. Rev., 115, 1083-1126, doi:10.1175/ 1520-0493(1987)115<1083:CSAPOL>2.0.CO;2.

Bradbury, J. A., S. L. Dingman, and B. D. Keim, 2002a: New England drought and relations with large scale atmospheric circulation patterns. J. Amer. Water Resour. Assoc., 38, 12871299, doi:10.1111/j.1752-1688.2002.tb04348.x.

— B. D. Keim, and C. P. Wake, 2002b: U.S. East Coast trough indices at $500 \mathrm{hPa}$ and New England winter climate variability. J. Climate, 15, 3509-3517, doi:10.1175/1520-0442(2002)015<3509: USECTI $>2.0 . \mathrm{CO} ; 2$.

- - , and,- 2003 : The influence of regional storm tracking and teleconnections on winter precipitation in the northeastern United States. Ann. Assoc. Amer. Geogr., 93, 544-556, doi:10.1111/1467-8306.9303002.
Brown, S. J., J. Caesar, and C. A. T. Ferro, 2008: Global changes in extreme daily temperature since 1950. J. Geophys. Res., 113, D05115, doi:10.1029/2006JD008091.

Cayan, D. R., K. T. Redmond, and L. G. Riddle, 1999: ENSO and hydrologic extremes in the western United States. J. Climate, 12, 2881-2893, doi:10.1175/1520-0442(1999)012<2881: EAHEIT $>2.0 . \mathrm{CO} ; 2$.

Coleman, J. S., and J. C. Rogers, 2003: Ohio River valley winter moisture conditions associated with the Pacific-North American teleconnection pattern. J. Climate, 16, 969-981, doi:10.1175/ 1520-0442(2003)016<0969:ORVWMC >2.0.CO;2.

Dominguez, F., and P. Kumar, 2005: Dominant modes of moisture flux anomalies over North America. J. Hydrometeor., 6, 194209, doi:10.1175/JHM417.1.

Easterling, D. R., G. A. Meehl, C. Parmesan, S. A. Changnon, T. R. Karl, and L. O. Mearns, 2000: Climate extremes: Observations, modeling, and impacts. Science, 289, 2068-2074, doi:10.1126/ science.289.5487.2068.

Frankoski, N. J., and A. T. DeGaetano, 2011: An East Coast winter storm precipitation climatology. Int. J. Climatol., 31, 802-814, doi:10.1002/joc. 2121.

Frich, P., L. V. Alexander, P. Della-Marta, B. Gleason, M. Haylock, A. M. G. Klein Tank, and T. Peterson, 2002: Observed coherent changes in climatic extremes during the second half of the twentieth century. Climate Res., 19, 193-212, doi:10.3354/ cr019193.

Gershunov, A., and T. P. Barnett, 1998: ENSO influence on intraseasonal extreme rainfall and temperature frequencies in the contiguous United States: Observations and model results. 
J. Climate, 11, 1575-1586, doi:10.1175/1520-0442(1998)011<1575: EIOIER $>2.0 . \mathrm{CO} ; 2$.

Goodess, C. M., and Coauthors, 2005: STARDEX downscaling climate extremes. Climatic Research Unit Tech. Rep., 21 pp. [Available online at http://www.cru.uea.ac.uk/projects/stardex/ reports/STARDEX_FINAL_REPORT.pdf.]

Griffiths, M. L., and R. S. Bradley, 2007: Variations of twentiethcentury temperature and precipitation extreme indicators in the northeast United States. J. Climate, 20, 5401-5417, doi:10.1175/ 2007JCLI1594.1.

Hartley, S., and M. J. Keables, 1998: Synoptic associations of winter climate and snowfall variability in New England, USA, 1950-1992. Int. J. Climatol., 18, 281-298, doi:10.1002/ (SICI)1097-0088(19980315)18:3<281::AID-JOC245>3.0.CO;2-F.

Higgins, R. W., A. Leetmaa, and V. E. Kousky, 2002: Relationships between climate variability and winter temperature extremes in the United States. J. Climate, 15, 1555-1572, doi:10.1175/ 1520-0442(2002)015<1555:RBCVAW > 2.0.CO;2.

Hoerling, M. P., A. Kumar, and M. Zhong, 1997: El Niño, La Niña, and the nonlinearity of their teleconnections. J. Climate, 10, 1769-1786, doi:10.1175/1520-0442(1997)010<1769: ENOLNA $>2.0 . \mathrm{CO} ; 2$.

Hurrell, J. W., and H. van Loon, 1997: Decadal variations in climate associated with the North Atlantic Oscillation. Climatic Change, 36, 301-326, doi:10.1023/A:1005314315270.

Kenyon, J., and G. C. Hegerl, 2008: Influence of modes of climate variability on global temperature extremes. J. Climate, 21, 3872-3889, doi:10.1175/2008JCLI2125.1.

$\longrightarrow$, and — 2010: Influence of modes of climate variability on global precipitation extremes. J. Climate, 23, 6248-6262, doi:10.1175/ 2010JCLI3617.1.

Kug, J.-S., S.-I. An, Y.-G. Ham, and I.-S. Kang, 2010: Changes in El Niño and La Niña teleconnections over North Pacific-America in the global warming simulations. Theor. Appl. Climatol., 100, 275-282, doi:10.1007/s00704-009-0183-0.

Kunkel, K. E., and J. R. Angel, 1999: Relationship of ENSO to snowfall and related cyclone activity in the contiguous United States. J. Geophys. Res., 104, 19425-19434, doi:10.1029/ 1999JD900010.

Leathers, D. J., B. Yarnal, and M. A. Palecki, 1991: The Pacific/North American teleconnection pattern and United States climate. Part I: Regional temperature and precipitation associations. J. Climate, 4, 517-528, doi:10.1175/1520-0442(1991)004<0517: TPATPA $>2.0 . \mathrm{CO} ; 2$.

Loikith, P. C., and A. J. Broccoli, 2014: The influence of recurrent modes of climate variability on the occurrence of winter and summer extreme temperatures over North America. J. Climate, 27, 1600-1618, doi:10.1175/JCLI-D-13-00068.1.

Maurer, E. P., A. W. Wood, J. C. Adam, D. P. Lettenmaier, and B. Nijssen, 2002: A long-term hydrologically based dataset of land surface fluxes and states for the conterminous United States. J. Climate, 15, 3237-3251, doi:10.1175/1520-0442(2002)015<3237: ALTHBD $>2.0 . C O ; 2$.

Mearns, L. O., R. W. Katz, and S. H. Schneider, 1984: Extreme hightemperature events: Changes in their probabilities with changes in mean temperature. J. Climate Appl. Meteor., 23, 1601-1613, doi:10.1175/1520-0450(1984)023<1601:EHTECI>2.0.CO;2.

Meehl, G. A., and C. Tebaldi, 2004: More intense, more frequent, and longer lasting heat waves in the 21 st century. Science, $\mathbf{3 0 5}$, 994-997, doi:10.1126/science.1098704.
Ning, L., and Y. Qian, 2009: Interdecadal change in extreme precipitation over south China and its mechanism. Adv. Atmos. Sci., 26, 109-118, doi:10.1007/s00376-009-0109-x.

— , and R. S. Bradley, 2014: Winter precipitation variability and corresponding teleconnections over the northeastern United States. J. Geophys. Res. Atmos., 119, 7931-7945, doi:10.1002/ 2014JD021591.

, M. E. Mann, R. Crane, and T. Wagener, 2012a: Probabilistic projections of climate change for the mid-Atlantic region of the United States: Validation of precipitation downscaling during the historical era. J. Climate, 25, 509-526, doi:10.1175/ 2011JCLI4091.1.

—, - —, —, ——, R. G. Najjar Jr., and R. Singh, 2012b: Probabilistic projections of anthropogenic climate change impacts on precipitation for the mid-Atlantic region of the United States. J. Climate, 25, 5273-5291, doi:10.1175/ JCLI-D-11-00565.1.

Notaro, M., W.-C. Wang, and W. Gong, 2006: Model and observational analysis of the northeast U.S. regional climate and its relationship to the PNA and NAO patterns during early winter. Mon. Wea. Rev., 134, 3479-3505, doi:10.1175/ MWR3234.1.

Peixoto, J. P., and A. H. Oort, 1992: Water cycle. Physics of Climate, Springer, 270-307.

Ropelewski, C. F., and M. S. Halpert, 1986: North American precipitation and temperature patterns associated with the El Niño/ Southern Oscillation (ENSO). Mon. Wea. Rev., 114, 2352-2362, doi:10.1175/1520-0493(1986)114<2352:NAPATP > 2.0.CO;2.

Straus, D. M., and J. Shukla, 2002: Does ENSO force the PNA? J. Climate, 15, 2340-2358, doi:10.1175/1520-0442(2002)015<2340: DEFTP $>2.0 . \mathrm{CO} ; 2$.

Trenberth, K. E., 1997: The definition of El Niño. Bull. Amer. Meteor. Soc., 78, 2771-2777, doi:10.1175/1520-0477(1997)078<2771: TDOENO $>2.0 . \mathrm{CO} ; 2$

_ climate change. Climate Change 2007: The Physical Science Basis, S. Solomon et al., Eds., Cambridge University Press, 235-336.

Villarini, G., J. A. Smith, and G. A. Vecchi, 2013: Changing frequency of heavy rainfall over the central United States. J. Climate, 26, 351-357, doi:10.1175/JCLI-D-12-00043.1.

Wallace, J. M., and D. S. Gutzler, 1981: Teleconnections in the geopotential height field during the Northern Hemisphere winter. Mon. Wea. Rev., 109, 784-812, doi:10.1175/ 1520-0493(1981)109<0784:TITGHF>2.0.CO;2.

Westby, R. M., Y.-Y. Lee, and R. X. Black, 2013: Anomalous temperature regimes during the cool season: Long-term trends, low-frequency mode modulation, and representation in CMIP5 simulations. J. Climate, 26, 9061-9076, doi:10.1175/ JCLI-D-13-00003.1.

Wettstein, J. J., and L. O. Mearns, 2002: The influence of the North Atlantic-Arctic Oscillation on mean, variance, and extremes of temperature in the northeastern United States and Canada. J. Climate, 15, 3586-3600, doi:10.1175/1520-0442(2002)015<3586: TIOTNA $>2.0 . \mathrm{CO} ; 2$.

Wigley, T. M. L., 1985: Climatology: Impact of extreme events. Nature, 316, 106-107, doi:10.1038/316106a0.

Yarnal, B., and D. J. Leathers, 1988: Relationships between interdecadal and interannual climatic variations and their effect on Pennsylvania climate. Ann. Assoc. Amer. Geogr., 78, 624-641, doi:10.1111/j.1467-8306.1988.tb00235.x. 